\title{
Occupational structures across 25 EU countries: the importance of industry structure and technology in old and new EU countries
}

Citation for published version (APA):

Cörvers, F., \& Meriküll, J. (2008). Occupational structures across 25 EU countries: the importance of industry structure and technology in old and new EU countries. Researchcentrum voor Onderwijs en Arbeidsmarkt, Faculteit der Economische Wetenschappen. ROA Research Memoranda No. 2 https://doi.org/10.26481/umaror.2008002

Document status and date:

Published: 01/01/2008

DOI:

10.26481/umaror.2008002

Document Version:

Publisher's PDF, also known as Version of record

Please check the document version of this publication:

- A submitted manuscript is the version of the article upon submission and before peer-review. There can be important differences between the submitted version and the official published version of record.

People interested in the research are advised to contact the author for the final version of the publication, or visit the DOI to the publisher's website.

- The final author version and the galley proof are versions of the publication after peer review.

- The final published version features the final layout of the paper including the volume, issue and page numbers.

Link to publication

\footnotetext{
General rights rights.

- You may freely distribute the URL identifying the publication in the public portal. please follow below link for the End User Agreement:

www.umlib.nl/taverne-license

Take down policy

If you believe that this document breaches copyright please contact us at:

repository@maastrichtuniversity.nl

providing details and we will investigate your claim.
}

Copyright and moral rights for the publications made accessible in the public portal are retained by the authors and/or other copyright owners and it is a condition of accessing publications that users recognise and abide by the legal requirements associated with these

- Users may download and print one copy of any publication from the public portal for the purpose of private study or research.

- You may not further distribute the material or use it for any profit-making activity or commercial gain

If the publication is distributed under the terms of Article $25 \mathrm{fa}$ of the Dutch Copyright Act, indicated by the "Taverne" license above, 


\title{
Occupational Structures across 25 EU Countries: The Importance of Industry Structure and Technology in Old and New EU Countries
}

\author{
Frank Cörvers \\ Jaanika Meriküll \\ ROA-RM-2008/2 \\ February 08
}

Research Centre for Education

and the Labour Market

P.O. Box 616

6200 MD Maastricht

The Netherlands

E-mail: $\quad$ secretary@roa.unimaas.nl

Internet: $\quad \underline{w w w . r o a . u n i m a a s . n l}$

Maastricht University

Faculty of Economics and Business Administration 
The ROA Research Memorandum Series was created in order to make research results available for discussion, before those results are submitted for publication in journals.

Sec08.019.pdf 
ROA-RM-2008/2 » http://www.roa.unimaas.nl/resmem.htm

\section{Abstract \\ Occupational Structures across 25 EU Countries: The Importance of Industry Structure and Technology in Old and New EU Countries}

This paper analyzes the occupational structures of 25 European Union countries during the period 2000-2004. Shift-share analyses have been used to decompose cross-country differences in occupational structure into within industry and between industry effects. The static analysis for 2004 shows that the new Member States employ a lower share of skilled workers because their industry structure is biased towards less skill-intensive industries and because they use fewer skills within industries. The differences in the shares of (high-skilled) non-production workers are dominated by the between (industrial) effect. In contrast, the dynamic analysis of 2000-2004 shows that changes in the share of high-skilled non-production workers are mostly driven by within industry changes, which are probably related to skill-biased technological change. The results indicate the weakening of this process, at least for non-production workers. The diffusion of the increased demand for skills within sectors is witnessed for the higher income EU12 country group, but less strongly for the EU25 country group.

Keywords: Industry structure, occupational structure, technological change, technology diffusion, transition economies

Theme: Cross-country investigation of skill-biased technological change JEL: J21, J24, O33, P23 
Frank Cörvers

ROA

P.O. Box 616

6200 MD Maastricht

f.coervers@roa.unimaas.nl
Jaanika Meriküll

Faculty of Economics and Business

Administration

University of Tartu

Narva rd 4

51009 Tartu

Estonia

jaanika.merikull@mtk.ut.ee 


\section{Introduction}

Many countries have witnessed a marked increase in the demand for skilled workers since the 1970s. These developments have been registered in high-income as well as in developing countries. The most common explanation for these developments has been skill-biased technological change (SBTC) stemming from progress in, for example, Information and Communication Technologies (ICT) (Autor, Katz, Krueger 1998; Kelly 2007). Positive relations have been found also between demand for skills and research and development expenditures, innovation or other technology proxy variable. Alternative explanations for these upgrading of skills have been globalisation via foreign trade (Morrison Paul and Siegel 2001), including outsourcing (Geishecker 2006; Minondo and Rubert 2006); and organisational change (Caroli and Van Reenen 2001; Piva et al. 2005).

The empirical literature investigating skill-biased technological change has mostly concentrated on high-income countries ${ }^{1}$, but some recent contributions have investigated the issue for less developed countries (Kijima 2006 for India; Kang and Hong 2002 for Korea). The cross-country analysis of skills upgrading usually proceeds from shift-share analysis. The shift-share analysis disentangles a country's skills upgrading into between industry and within industry effects. Between industry effects capture changes in the skill structure due to shifts in the industry composition, while within industry effects capture changes due to shifts in individual industries' skill structure. The within industry developments in the demand for skills are mostly attributed to technological change, but organizational change and trade could also play a role. The crosscountry comparative studies have also limited themselves to developed OECD countries (Berman et al. 1998) or added a scattered selection of developing countries around the world (Berman and Machin 2000).

From this it follows that under a straightforward decomposition, a country's skills structure is a combination of the developments between industries and within industries. Reallocation of labour between industries is usually related to the level of economic development in a country. Raiser et al. (2004) have summarized the cross-country studies on the relationship between employment structures and economic development. They concluded that the richer the country, the smaller its employment share in agriculture and industry, and the larger its employment share in services. Elsewhere, developments in within-industry skill structures were found to be similar in high and middle income countries (Berman and Machin 2000). Continuing along this line of thought, countries at different levels of economic development should display similar developments in skill structures within industries, but independent developments between industries.

In 2004, the European Union entered a new era, because ten new less-developed countries joined the union, of which eight were post-Soviet states. The long-term goal of the EU is not only to become the most competitive economy in the world (Blanke 2006), but also the convergence of the Member States' income levels (The Council of the European Union 1999). One of the key factors behind economic growth is the amount and quality of the production factors. Labour decomposition in a country provides a straightforward picture of where the country is standing in

\footnotetext{
${ }^{1}$ E.g. Autor et al. 1998, Morrison Paul and Siegel 2001, Baltagi and Rich 2005 for the US; Berman, Bound and Machin 1998 for the US, UK and selected developed countries; Gera et al. 2001 for Canada; Edwards 2004 for South Africa; Salvanes and Førre 2003 for Norway; Sakurai 2001 for Japan; Kelly 2007 for Australia.
} 
terms of its industry structure and within-industry skill use. The target of income convergence for countries cannot be achieved if some countries operate with less advantageous industry structures or production technology. Investigation of the dynamic developments in skill structures makes it possible to explain past developments and provide input for future developments. Expectancies about future developments in skill structures again provide essential input for educational and labour market policies.

The purpose of this paper is to investigate developments in skill structures in EU countries. We will address the question whether countries at different levels of development undergo similar or different developments in skill decomposition between and within industries. To do so, we will classify the components of the developments in skill structures for 25 EU Member States in a static and a dynamic framework. We will also test the simultaneity of within industry skills upgrading across countries, tracking down technology spillovers across EU members. Two definitions of skilled workers will be used: the employment share of non-production occupations and the employment share of high-skilled non-production occupations ${ }^{2}$. In terms of time, we will take the period of 2000-2004 for the dynamic analysis and the year 2004 for the static analysis.

Our study contributes to the literature in two areas. First, we cover the skill structure of a broad range of countries at different stages of development, but from one geographical region. Both the post-communist new EU countries and the “old” high-income Western EU members are included in the study, which enables us to compare the results across two groups of countries. The strong points of our study are representativeness and comparability of the data as we proceed from methodologically comparable labour force surveys of individual countries. Second, unlike the existing literature, we also provide a static analysis of the countries' skill structures. Contrary to the dynamic analysis, the individual countries are not compared to their mean over time, but to the average of the group of countries. This approach is an effective tool, providing a straightforward explanation as to why any particular country lacks behind in skill use: whether it is due to the industry structure or to the within industry skill composition. This methodology is a potential tool for similar studies using cross-sectional data of countries with diverse economic backgrounds.

Our results suggest that in a static framework the between industry effects explain most of the differences in the countries' skill structures. In a dynamic analysis, similarly to previous studies, we find that the within industry effect is behind most of the changes in skills structure, likely as a result of skill-biased technological change. Within industries skills upgrading is, especially in high-income EU members, similar in the same industries across countries, possibly reflecting the technology diffusion over the EU.

The paper is organized as follows. The next section provides some background information and an overview of previous empirical studies. Section 3 describes the data. Section 4 presents the static analysis of EU skill structures in 2004. Section 5 presents the changes in EU occupational

\footnotetext{
${ }^{2}$ Alternative measures of skills could be the wage bill share of non-production workers, the share of university degree workers or a codification of a special skill (e.g. cognitive) in a particular occupation. Despite minor differences between the occupational classifications used in different countries, the International Standard Classification of Occupations (ISCO-88) is considered to be consistent across countries at the aggregated level (Elias and McNight 2001).
} 
structures over the period 2000-2004 and discusses the correlations between the within industry developments. The last section summarizes the results.

\section{Background}

The countries under investigation in this paper have very diverse economic backgrounds. The group of countries includes all Members States of the EU in the year 2004, including the 10 new Member States (NMS10) that joined in 2004, of which eight were post-Soviet countries. In terms of macrovariables, in 2002, labour productivity in the new EU countries was approximately 50\% of that of the old EU15 members. The new members' GDP per capita in purchasing power parity adjusted terms amounted to $46.4 \%$ of the EU15 average, and the unemployment rate was almost twice as high (14.7\% compared to 7.7\%) as the EU15 average (European Commission 2003a, p. 44).

The differences in the relative prices of labour and capital are also noticeable. Labour costs in the new Member States were considerably lower than those in the EU15 countries. In 2003, monthly labour costs in the EU15 were 3,333 EUR, while the labour costs in NMS10 amounted to only approximately one fourth of this amount, or 887 EUR (Eurostat database 2005). Capital costs were also in favour of the new members, although the differences in capital costs are not comparable to those in labour costs. The implicit tax rate on capital income for EU15 was 19.2\%, whereas for new members it was $12.8 \%$; the average statutory tax rate on corporate income was 30.1\% for old members and 20.6\% for new members (European Commission 2005, pp. 88, 93). ${ }^{3}$

According to the Heckschler-Ohlin model, the new Member States that witness a lower relative price of labour should be net exporters of labour-intensive goods, whereas the old Member States should be net exporters of capital-intensive goods (see e.g. Leamer 1984; 1992). Taking into account the complementarity of capital and high-skilled labour, and the substitutability between capital and low-skilled labour, the occupational structure of the new members compared to the old members should be inclined towards low-skilled labour.

However, the coexistence of diffusion of technology from the new to the old members and the witnessed skill-biased technological change in the old Member States, should over time lead to skills upgrading for both country groups. The diffusion of new technologies may take place via both international trade and capital flows, in particular via foreign direct investments (FDI). Barrell and Pain (1997) estimated the role of FDI in the process of technological change in developed Europe, proceeding from FDI instead of total capital flows as the former are “intimately connected to the transfer of technologies between nations" (Barrell and Pain 1997, pp. 1770-1771). In 2001-2003, the accumulated FDI inflow from outside the EU25 countries to new member countries (then accession countries) amounted to only $17 \%$ of the total flows to accession countries (Eurostat 2005, p. 52). Thus, a large share of the new members' FDI originates from the EU15 countries.

\footnotetext{
${ }^{3}$ Many observations on implicit tax rates are lacking for the new member countries. The countries included in the NMS10 figures are the Czech Republic, Estonia, Lithuania and Slovakia. One should also notice that the tax bases could differ across countries.
} 
Berman et al. (1998) found evidence for a skill-biased technological change (SBTC) in both developed and developing countries. They carried out a cross-country analysis, based on the argument that due to modern international communication and trade, the technological change occurring in one country (notably the USA) is quickly adopted in other countries. Moreover, the more intensive use of labour-saving technologies decreases the demand for low-skilled workers all over the world. They tested their hypothesis by decomposing the differences in the employment share of non-production workers (which they considered to be skilled) into between industry and within industry components. According to their cross-country comparison of manufacturing sectors in the world's 12 richest countries (in terms of GNP per capita), the share of skilled workers increased in all of the investigated countries during the 1970s and 1980s, amounting on average to a 0.4 and 0.3 percentage point increase per year, respectively. The increase is largely attributed to the within effect, which accounted for $84 \%$ and $92 \%$ of the change in the respective decades. Thus, the increase in the share of skilled workers was mostly the result of shifts towards skilled workers within industries, instead of a different employment allocation between industries (Berman et al. 1998, pp. 1257-1258). This within industry effect towards skilled labour can be interpreted as evidence for skill-biased technological change. Similarly, the above-mentioned authors found that the increase in the share of skilled workers, in spite of increasing or stabilized relative wages for these workers, indicated SBTC in developing countries (Berman et al. 1998, p. 1271).

Empirical research on skill-biased technological change has used two methods to detect similar trends across countries in skill-biased technological change (Berman and Machin 2000, p. 18). One method tests whether skills upgrading has occurred in the same industries across countries. The other method tests for technology transfers as correlations between skills upgrading and some global input indicator of technological change (computer usage, R\&D intensity, see e.g. Machin and Van Reenen (1998)). In this paper, the first method is used. In addition to testing the simultaneous spread of the technological change also the correlations between countries' within industry skills upgrading are investigated (see Berman and Machin 2000).

\section{Data}

The analysis of this paper employs micro data from Labour Force Surveys for each of the 25 countries being members of the EU since May 2004. The data have been collected in each of the EU Member States and are supplied to Eurostat by each Member State. Member States have the obligation to provide data compatible with EU definitions and to follow the same quality standards (European Commission 2006).

The sampling design of EU Labour force surveys varies across the Member States, but the results are weighted so as to represent the working age population of a country. The working age population has been defined in most of the countries as the age group "15+" or "15-74". Most of the surveys are quarterly rotating panel surveys with an average sampling rate of $0.49 \%$ per quarter in second quarter of 2004. (European Commission 2006) Labour Force survey estimates per year have been used for this paper. Because, first, changes in skill structure are time consuming and quarterly data do not provide any additional insights about the problem and, second, yearly data increases the reliability of the estimates. 
The queries for the data sets used in this paper were made in Eurostat and were provided to the authors. For each country the data set includes the employment distribution across industries and occupations. The occupational distribution of EU Labour Force surveys follows the ISCO88 classification, i.e. International Standard Classification of Occupations of the International Labour Organization (ILO). The ISCO occupational groups were provided to authors at the onedigit level, containing 10 major occupational groups and one group where occupation was unknown (see appendix A). The industry distribution of EU Labour Force surveys follows the NACE Rev. 1 classification, i.e. Statistical Classification of Economic Activities in the European Community. Again the industry classification was provided at the one-digit level including 17 major industries plus one group where industry type was unknown (see appendix B), cf. European Commission (2003b).

Both of the classifications are also comparable outside the EU. The ISCO is as ILO reference classification internationally well recognised and widely used. The NACE classification is closely related to the ISIC Rev. 3 classification, i.e. United Nations (UN) International Standard Industrial Classification of All Economic Activities. The latter is a UN reference classification that is a product of international agreement and has been followed by many countries internationally (see European Commission: CIRCA 2008).

Eurostat provided these survey estimates of industries' occupational distribution as yearly employment volumes, all further calculations have been made by the authors. The time span is reduced to 2000-2004 as for this period data were available for all of the 25 countries which were EU members from May 2004.

\section{Static analysis, 2004}

\subsection{Cross-country shift-share analysis}

This section investigates the cross-country differences of the occupational structures in the EU25 countries for one year, 2004. The static cross-country shift-share analysis is used to distinguish between the between and within sectors effects. The methodology is adopted from Esteban (2000), who used the methodology to decompose EU regional productivity differentials.

The number of countries, $k$, in the analysis is $25, k=1, \ldots, 25$. The occupational shares are based on the one-digit ISCO classification level ('major groups'), $j=1, \ldots, 11$, with one occupational group added to account for the share of unknown occupations (see Appendix A). The industry shares are presented at the one-digit NACE classification level, $i=1, \ldots, 18$, where again one sector includes all unknown economic activities (see Appendix B).

The deviation of a particular country's occupational structure from the average occupational structure in the EU countries has been decomposed into three effects: the between effect $\left(I_{j}^{k}\right)$, the within effect $\left(I I_{j}^{k}\right)$ and the interaction effect $\left(I I I_{j}^{k}\right)$. The between effect is also referred to as the industry mix component, or the industrial effect, whereas the within effect is also labelled as the occupational effect or the technology effect. 
The difference between country $k$ 's share of occupation $j$ and the EU25 cross-country average share of occupation $j$ is denoted as $d_{j}^{k}$. This difference is the sum of the between, within and interaction effects:

$$
d_{j}^{k}=o_{j}^{k}-\bar{o}_{j}=I_{j}^{k}+I I_{j}^{k}+I I I_{j}^{k}, \quad j=1, \ldots, 11 .
$$

The variable $o_{j}^{k}$ denotes the share of occupation $j$ of total occupation in country $k$. The variable $\bar{o}_{j}$ is the EU25 cross-country average of the share of occupation $j$ of total occupation and is calculated as follows: $\bar{o}_{j}=\sum_{k} o_{j}^{k} / 25, k=1, \ldots, 25$.

The shares of each occupation sum up to one for each country $k$ and also for the EU average, i.e. $\sum_{j} o_{j}^{k}=1$ and $\sum_{j} \bar{o}_{j}=1$. The shares of each occupation for each industry and the shares of each industry sum up to one for every country, i.e. $\sum_{j} o_{i j}^{k}=1$ for every industry $i$ and country $k$; $\sum_{i} \bar{o}_{i j}=1$ for every industry $i$ and $\sum_{i} s_{i}^{k}=1$ for every country $k, \sum_{i} \bar{s}_{i}=1$ for the cross-country average, where $\bar{o}_{i j}=\sum_{k} o_{i j}^{k} / 25$ and $\bar{s}_{i}=\sum_{k} s_{i}^{k} / 25$.

The between effect $\left(I_{j}^{k}\right)$ captures the differences in the occupational structures due to the differences in the employment allocation between sectors:

$$
I_{j}^{k}=\sum_{i} \bar{o}_{i j}\left(s_{i}^{k}-\bar{s}_{i}\right) .
$$

The variable $\bar{o}_{i j}$ denotes the EU average of the share of occupation $j$ in industry $i, s_{i}^{k}$ is the employment share of industry $i$ in country $k$, and $\bar{s}_{i}$ is the EU average of the employment share of industry $i$. If the occupational structure within the production sectors of a country were equal to the EU average for every economic activity, then the differences in the country's overall occupational structure would be wholly accounted for by the differences in employment allocation between the production sectors. In other words, if the technology in use within a production sector were the same for all the EU countries, the occupational structures of individual countries could still differ because of the different importance of each production sector.

The within effect $\left(I I_{j}^{k}\right)$ shows the differences in the overall occupational structure due to the different occupational structures of each production sector:

$$
I I_{j}^{k}=\sum_{i}\left(o_{i j}^{k}-\bar{o}_{i j}\right) \bar{s}_{i} .
$$

The variable $o_{i j}^{k}$ denotes the share of occupation $j$ in industry $i$ in country $k, \bar{o}_{i j}$ is the corresponding variable for the EU, and $\bar{s}_{i}$ is the employment share in industry $i$ for EU. If the industry structure in terms of employment were the same across the EU countries, a country's overall occupational structure could differ because of the different occupational structures within industries. Thus, the within effect reflects the differences in occupational structures due to differences in the technologies used in the same production sectors. 
The interaction effect ( $I I I_{j}^{k}$ ) accounts for the effect of the interaction between the share of occupation $j$ across industries and the employment shares of industries. The interaction effect is positive if, compared to the EU average, a particular country's occupation $j$ is more important for the sectors that the country is specialized in, or occupation $j$ is unimportant for the sectors that the country is not specialized in. The opposite holds if occupation $j$ is unimportant for the sectors that a country is specialized in, or occupation $j$ is important for the sectors that the country is not specialized in. The interaction effect is derived as follows:

$$
I I I_{j}^{k}=\sum_{i}\left(o_{i j}^{k}-\bar{o}_{i j}\right)\left(s_{i}^{k}-\bar{s}_{i}\right) .
$$

The sum of the between, within and interaction effects for a particular occupation in a country is equal to the total difference between the share of the occupation in the country and the crosscountry average share of the occupation in the EU25 (see equation 1).

\subsection{Shift-share analysis 2004}

The differences between the employment shares of each occupation in individual countries and the corresponding EU average for 2004, are shown in Appendix C. A positive (negative) sign implies that a country's share of an occupation is above (below) the EU25 average. The armed forces (isco 0) and the unknown occupational group are left out of the discussion for the rest of the analysis (see Appendix A for the isco classification). Occupation groups isco 1-3 comprise the high-skilled non-production occupations: legislators, senior officials and managers (isco 1), professionals (isco 2), technicians and associate professionals (isco 3). For isco 1, the UK and Ireland are clearly above the cross-country average, whereas Cyprus is significantly below. For isco 2, Belgium and the Netherlands have the highest occupational shares, whereas Portugal has the lowest share. For isco 3, Austria and Germany have the highest shares, and Ireland and Greece the lowest.

The groups isco 4 and 5 represent the low-skilled non-production occupations: clerks (isco 4) and service workers as well as shop and market sales workers (isco 5). Belgium and Luxembourg have the highest, and Lithuania and Estonia the lowest shares in isco 4. For isco 5, Sweden has the highest, and Italy and Belgium the lowest shares. The groups isco 6 to 8 represent the skilled production occupations: skilled agricultural and fishery workers (isco 6), craft and related trades workers (isco 7), and plant and machine operators together with assemblers (isco 8). Poland has by far the highest share in isco 6. The Czech Republic and Slovakia have the highest shares in isco 7, while the Netherlands has the lowest share in this occupational group. Slovenia has the highest, and Cyprus the lowest share in isco 8. Finally, for the unskilled production occupations in isco 9 (elementary occupations), Cyprus and Spain have the highest, and Slovenia and Sweden the lowest shares.

It is difficult to draw general conclusions by comparing country's every isco group shares to the cross-country EU averages. This also holds when for each occupational group the total differences between the national and the EU averages are decomposed into the industrial, within

and interaction effects. These effects are shown in Appendix D, and will not be discussed further. Instead Tables 1 and 2 present the results of a shift-share analysis for the year 2004 with the 
number of occupational groups reduced to two, in order to facilitate the presentation of the results. The major occupational groups have been aggregated into two occupational classes in two different ways:

1) Non-production versus production occupations.

2) High-skilled non-production versus all other occupations (i.e., low-skilled non-production and production).

The first division, the non-production versus production division, is widely used in the literature of skill-biased technological change, although until now only for dynamic analyses (Berman et al. 1998, Berman et al. 2000). The second division, the high-skilled non-production versus the remaining occupations, is used to check whether the results are robust to different definitions of skills.

It follows that the new Member States employ fewer workers in non-production (Table 1) and high-skilled non-production (Table 2) occupations than the old Member States. The correlation between the share of non-production occupations or the share of high-skilled non-production occupations and a dummy variable characterizing the country type (old or new member), is significant at the 1\% level. Among the old Member States, Greece, Portugal and Spain have a low share of non-production and high-skilled non-production occupations, even by comparison with the new Member States. Therefore the variation is high within the old Member States group; the standard deviation is 0.069 for non-production and 0.059 for high-skilled non-production occupations. Within the EU15 group, the Netherlands has the highest share of non-production and high-skilled non-production occupations, while Portugal has the lowest shares. The NMS10 group is more homogeneous, with standard deviations of 0.038 and 0.029 , respectively. Only Lithuania and Poland stand out with low shares of non-production occupations, whereas Cyprus has a very low share of high-skilled non-production occupations.

Tables 1 and 2 show that the between effect dominates the within effect for both country groups and both skill classifications. However, there is no statistically significant correlation between either of the effects and the country type. 
Table 1. Shift-share decomposition of non-production occupations in the EU in 2004.

\begin{tabular}{|c|c|c|c|c|c|c|c|c|}
\hline \multirow[b]{2}{*}{ Belgium (BE) } & \multirow[t]{2}{*}{$\begin{array}{c}\text { Share in } \\
2004 \\
0.690\end{array}$} & \multirow[t]{2}{*}{$\begin{array}{c}\text { Difference } \\
\text { from EU25 } \\
\text { cross- } \\
\text { country } \\
\text { average } \\
\text { share } \\
0.071\end{array}$} & \multicolumn{2}{|c|}{$\begin{array}{l}\text { Between effect } \\
\text { (size and share, } \\
\%)\end{array}$} & \multicolumn{2}{|c|}{$\begin{array}{c}\text { Within effect } \\
\text { (size and share, } \\
\% \text { ) }\end{array}$} & \multicolumn{2}{|c|}{$\begin{array}{l}\text { Interaction effect } \\
\text { (size and share, } \\
\% \text { ) }\end{array}$} \\
\hline & & & 0.050 & 70 & 0.019 & 26 & 0.003 & 4 \\
\hline Austria (AT) & 0.656 & 0.038 & 0.020 & 53 & 0.022 & 58 & -0.004 & -11 \\
\hline Denmark (DK) & 0.676 & 0.057 & 0.050 & 86 & 0.003 & 5 & 0.005 & 9 \\
\hline Finland (FI) & 0.658 & 0.040 & 0.023 & 58 & 0.021 & 53 & -0.004 & -10 \\
\hline France (FR) & 0.638 & 0.020 & 0.026 & 130 & -0.001 & -5 & -0.005 & -25 \\
\hline Germany (DE) & 0.669 & 0.051 & 0.020 & 40 & 0.027 & 52 & 0.004 & 8 \\
\hline Greece (EL) & 0.580 & -0.038 & -0.021 & -55 & -0.012 & -30 & -0.006 & -15 \\
\hline Ireland (IE) & 0.694 & 0.076 & 0.003 & 4 & 0.081 & 107 & -0.008 & -11 \\
\hline Italy (IT) & 0.620 & 0.002 & $-0.5 e^{-3}$ & -25 & 0.0039 & 195 & -0.001 & -70 \\
\hline Luxembourg (LU) & 0.683 & 0.065 & 0.065 & 84 & 0.006 & 8 & 0.006 & 8 \\
\hline Netherlands (NL) & 0.743 & 0.125 & 0.052 & 42 & 0.078 & 62 & -0.005 & -4 \\
\hline Portugal (PT) & 0.492 & -0.126 & -0.062 & -50 & -0.054 & -43 & -0.010 & -7 \\
\hline Spain (ES) & 0.545 & -0.073 & -0.026 & -35 & -0.040 & -56 & -0.007 & -9 \\
\hline Sweden (SW) & 0.723 & 0.105 & 0.067 & 64 & 0.028 & 27 & 0.010 & 9 \\
\hline UK (UK) & 0.717 & 0.099 & 0.067 & 68 & 0.042 & 42 & -0.009 & -9 \\
\hline Czech Republic (CZ) & 0.578 & -0.040 & -0.041 & -103 & 0.008 & 20 & -0.007 & -18 \\
\hline Cyprus (CY) & 0.585 & -0.033 & -0.031 & -94 & 0.015 & 45 & -0.018 & -55 \\
\hline Estonia (EE) & 0.557 & -0.061 & -0.030 & -49 & -0.024 & -39 & 0.007 & 11 \\
\hline Hungary (HU) & 0.571 & -0.047 & -0.045 & -96 & 0.046 & 98 & -0.048 & -102 \\
\hline Latvia (LV) & 0.539 & -0.079 & -0.052 & -66 & -0.024 & -30 & -0.003 & -4 \\
\hline Lithuania (LT) & 0.475 & -0.143 & -0.063 & -44 & -0.069 & -48 & -0.012 & -8 \\
\hline Malta (MT) & 0.605 & -0.013 & 0.023 & 177 & -0.040 & -308 & 0.003 & 23 \\
\hline Poland (PL) & 0.506 & -0.112 & -0.070 & -62 & -0.024 & -21 & -0.019 & -17 \\
\hline Slovakia (SK) & 0.556 & -0.062 & -0.041 & -66 & -0.008 & -13 & -0.014 & -22 \\
\hline Slovenia (SI) & 0.565 & -0.053 & -0.055 & -104 & 0.010 & 19 & -0.008 & -15 \\
\hline EU15 average & 0.650 & 0.032 & 0.021 & 67 & 0.011 & 33 & 0 & 0 \\
\hline NMS10 average & 0.534 & -0.084 & -0.052 & -61 & -0.021 & -26 & -0.011 & -13 \\
\hline EU25 average & 0.633 & 0.015 & 0.0105 & 71 & 0.0040 & 27 & 0.0003 & 2 \\
\hline $\begin{array}{l}\text { EU25 cross-country } \\
\text { average }\end{array}$ & 0.618 & & & & & & & \\
\hline
\end{tabular}

Source: Labour Force Surveys from 25 EU countries, authors’ calculations. 
Table 2. Shift-share decomposition of high-skilled non-production occupations in the EU in 2004.

\begin{tabular}{|c|c|c|c|c|c|c|c|c|}
\hline \multirow[b]{2}{*}{ Belgium (BE) } & \multirow{2}{*}{$\begin{array}{c}\text { Share in. } \\
2004 \\
\\
0.425\end{array}$} & \multirow{2}{*}{$\begin{array}{c}\text { Difference } \\
\text { from EU25 } \\
\text { cross- } \\
\text { country } \\
\text { average } \\
\text { share } \\
0.045\end{array}$} & \multicolumn{2}{|c|}{$\begin{array}{c}\text { Between effect } \\
\text { (size and share, } \\
\% \text { ) }\end{array}$} & \multicolumn{2}{|c|}{$\begin{array}{c}\text { Within effect } \\
\text { (size and share, } \\
\% \text { ) }\end{array}$} & \multicolumn{2}{|c|}{$\begin{array}{l}\text { Interaction effec } \\
\text { (size and share, } \\
\% \text { ) }\end{array}$} \\
\hline & & & 0.039 & 87 & 0.010 & 22 & -0.004 & -9 \\
\hline Austria (AT) & 0.387 & 0.007 & 0.002 & 29 & 0.006 & 86 & -0.001 & -14 \\
\hline Denmark (DK) & 0.427 & 0.047 & 0.037 & 79 & 0.015 & 32 & -0.005 & -11 \\
\hline Finland (FI) & 0.427 & 0.047 & 0.024 & 51 & 0.031 & 66 & -0.008 & -17 \\
\hline France (FR) & 0.384 & 0.004 & 0.019 & 475 & -0.007 & -175 & -0.008 & -200 \\
\hline Germany (DE) & 0.421 & 0.041 & 0.015 & 36 & 0.021 & 53 & 0.005 & 11 \\
\hline Greece (EL) & 0.326 & -0.054 & -0.028 & -52 & -0.025 & -46 & -0.001 & -2 \\
\hline Ireland (IE) & 0.412 & 0.032 & -0.003 & -9 & 0.037 & 116 & -0.002 & -6 \\
\hline Italy (IT) & 0.395 & 0.015 & $-0.3 e^{-3}$ & -2 & 0.0016 & 11 & -0.001 & -7 \\
\hline Luxembourg (LU) & 0.454 & 0.074 & 0.041 & 55 & 0.025 & 34 & 0.008 & 11 \\
\hline Netherlands (NL) & 0.486 & 0.106 & 0.036 & 34 & 0.071 & 67 & -0.001 & -1 \\
\hline Portugal (PT) & 0.261 & -0.119 & -0.048 & -40 & -0.077 & -65 & 0.006 & 5 \\
\hline Spain (ES) & 0.309 & -0.071 & -0.031 & -44 & -0.041 & -58 & 0.001 & 1 \\
\hline Sweden (SW) & 0.440 & 0.060 & 0.062 & 103 & 0.016 & 27 & -0.018 & -30 \\
\hline UK (UK) & 0.406 & 0.026 & 0.044 & 169 & -0.003 & -12 & -0.015 & -58 \\
\hline $\begin{array}{l}\text { Czech Republic } \\
\text { (CZ) }\end{array}$ & 0.375 & -0.005 & $-2.4 \mathrm{e}^{-3}$ & -48 & 0.027 & 540 & -0.008 & -160 \\
\hline Cyprus (CY) & 0.284 & -0.096 & -0.028 & -29 & -0.057 & -59 & -0.011 & -12 \\
\hline Estonia (EE) & 0.384 & 0.004 & -0.012 & -300 & 0.018 & 450 & -0.002 & -50 \\
\hline Hungary (HU) & 0.341 & -0.039 & -0.004 & -10 & -0.028 & -73 & -0.007 & -17 \\
\hline Latvia (LV) & 0.333 & -0.047 & -0.031 & -67 & -0.009 & -18 & -0.007 & -15 \\
\hline Lithuania (LT) & 0.323 & -0.057 & -0.030 & -54 & -0.005 & 10 & -0.022 & -38 \\
\hline Malta (MT) & 0.335 & -0.045 & 0.001 & 2 & -0.049 & -109 & 0.003 & 7 \\
\hline Poland (PL) & 0.317 & -0.063 & -0.032 & -50 & -0.010 & -16 & -0.021 & -34 \\
\hline Slovakia (SK) & 0.353 & -0.027 & -0.018 & -68 & -0.005 & -18 & -0.004 & -14 \\
\hline Slovenia (SI) & 0.360 & -0.020 & -0.029 & -145 & 0.022 & 110 & -0.013 & -65 \\
\hline EU15 average & 0.393 & 0.013 & 0.013 & 100 & 0.0002 & 2 & $-0.7 e^{-3}$ & -5 \\
\hline NMS10 average & 0.336 & -0.044 & -0.025 & -56 & -0.008 & -19 & -0.011 & -25 \\
\hline EU25 average & 0.384 & 0.004 & 0.007 & 175 & -0.003 & -75 & $-0.1 e^{-3}$ & -3 \\
\hline $\begin{array}{l}\text { EU25 cross- } \\
\text { country average }\end{array}$ & 0.380 & & & & & & & \\
\hline
\end{tabular}

Source: Labour Force Surveys from 25 EU countries, authors’ calculations.

Figure 1 shows the results of the shift-share analysis for the non-production occupations, while Figure 2 shows these results for high-skilled non-production occupations. The figures summarize the results in Tables 1 and 2. The abbreviations of the countries used in the figures are included in the first column of Tables 1 and 2. For the old Member States of the EU15, the results are more or less similar, the exceptions being Greece, Portugal and Spain. In general, the old Member States employ more workers in high-level occupations, because their industrial structure is inclined towards the sectors that use more high-skilled workers, and because their industry production technologies rely more intensively on high-skilled workers. In this group, only the between effect for Ireland and the within effect for the UK depend on the choice of one or the other division. 


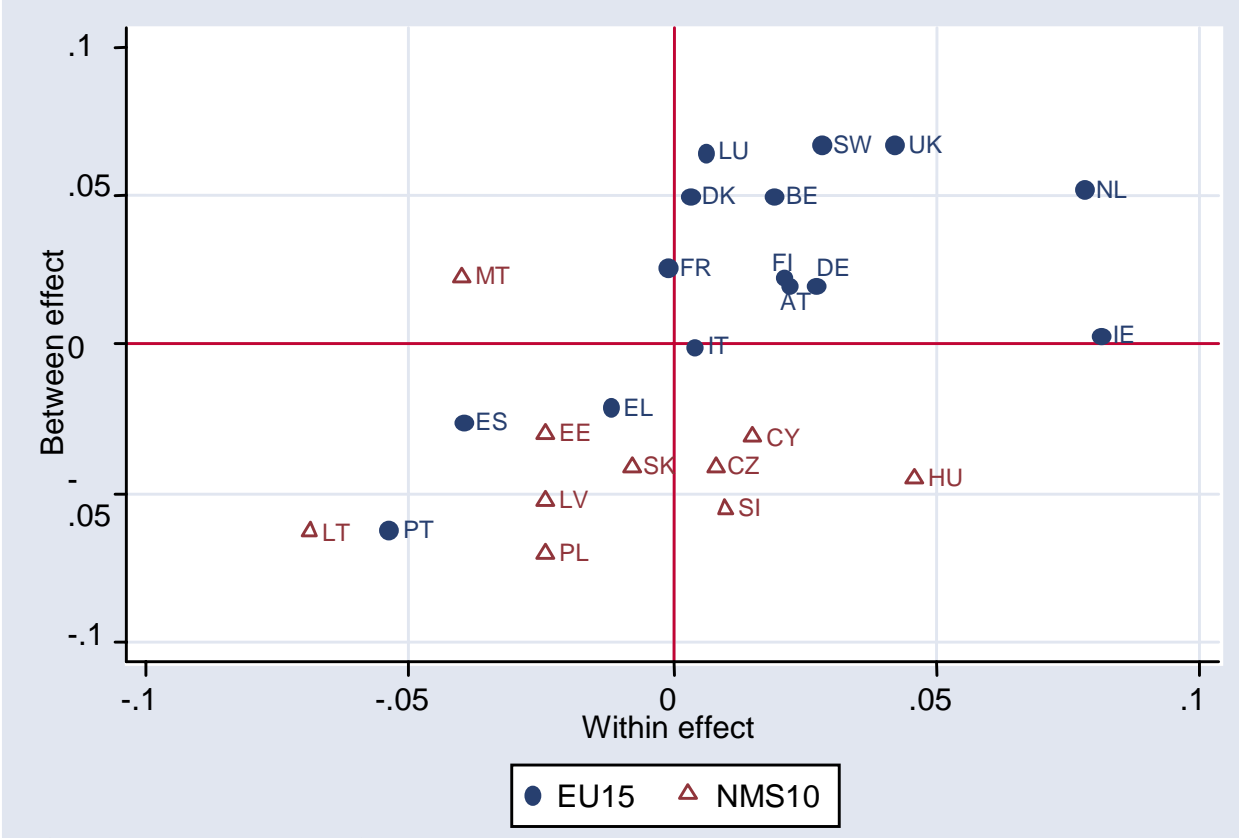

Source: Labour Force Surveys from 25 EU countries, authors' calculations.

Figure 1. The between and the within effects of the share of non-production occupations, 2004.

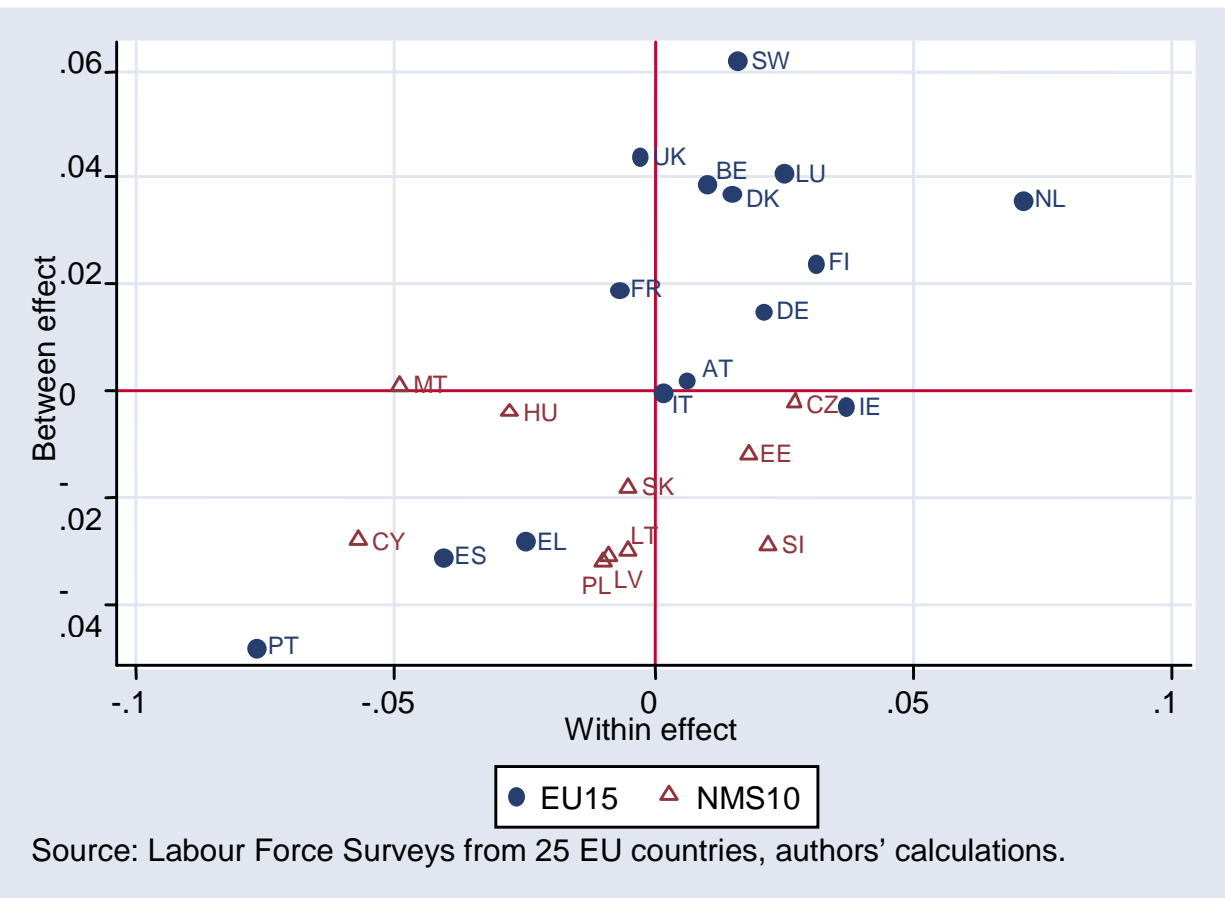

Figure 2. The between and the within effects of the share of high-skilled non-production occupations, 2004. 
Greece, Portugal and Spain among the old Member States, and Latvia, Lithuania, Poland and Slovakia among the new Member States employ fewer workers than on average in high-level occupations. This is due to their industry structure being inclined towards the sectors that employ more low-skilled workers, as well as production technology that intensively uses low-skilled workers. Malta is the only country consistently entering the category where the industry structure is inclined towards high-skilled workers, although the production technology is inclined towards low-skilled workers. The Czech Republic and Slovenia belong in both divisions to the group with a low-skill intensive industry structure and high-skill intensive production technology. The rest of the NMS10 group clearly employs more workers in industries that intensively use low-skilled workers, whereas the magnitude of the within effect (the technology in use) is dependent on the choice of measure of skilled occupations, i.e. high-skilled non-production occupations or all nonproduction occupations.

In sum, all the new member countries (except for Malta) employ relatively fewer skilled workers than the EU average because their industry structures are biased towards less skill-intensive industries. For the post-Soviet countries, this could be the continuing impact of the distorted Soviet industrial system, which relied extensively on agriculture and heavy industries. For crosscountry comparison, the overall trend is that the countries that employ more (less) skills do so because they use more (less) skill-intensive production technologies and because they rely more (less) on skill-intensive industries. Referring to the graphical description, this means that countries tend to locate around the $45^{\circ}$ line. However, the differences in the shares of (highskilled) non-production workers are rather dominated by the between (industrial) effect.

\section{Dynamic analysis, 2000-2004}

The time scale for the dynamic analysis comprises the period 2000-2004, i.e. four years before the accession of 10 new members and the year of the accession. The aim of this section is not to investigate directly the impact of the enlargement of the EU, but the development and possible convergence of the countries' skill structures under the ongoing process of European integration. Two exercises are undertaken to track the developments in EU skills structure. First, the upgrading of skills has been decomposed into between industry and within industry effects. Second, the similarities in within industry skills upgrading of individual industries has been examined.

\subsection{Shift-share analysis 2000-2004}

In this section, we will consider the changes over time in the occupational structures of skilled occupations for the 25 countries, which comprised the European Union after the 2004 accession. Again, the indication of skilled occupations is the employment share of non-production occupations and the employment share of high-skilled non-production occupations. 
For decomposition of the aggregate changes in the occupational structure, we distinguish between developments within industries and between industries (see e.g., Berman et al.1994, Berman et al. 1998 or Berman and Machin 2000). Therefore, the change in the share of (high-skilled) nonproduction occupations between 2000 and 2004 is given as:

$$
\Delta s=\sum_{i} \Delta s_{i} \bar{O}_{i}+\sum_{i} \Delta o_{i} \bar{s}_{i},
$$

where $o_{i}$ indicates the employment share of non-production (high-skilled non-production) occupations in industry employment, and $s_{i}$ indicates the employment share of a production sector in total employment. The production sectors are indicated by subscript $i, i=1, \ldots, 18$ (see Appendix B). A bar above the variables reflects an average over time. The change in the share of non-production (high-skilled non-production) occupations is equal to the sum of the between and the within effects. The between effect accounts for the changes in the occupational structure due to the changes in employment across industries, and the within effect for the changes due to developments within industries.

Table 3 reports the shares of non-production occupations and Table 4 the share of high-skilled non-production occupations in the EU countries for 2000 and 2004, and the decomposition of the changes. The main trend is that the share of skilled occupations has increased over the time investigated (see the fourth column in Tables 3 and 4). The share of non-production occupations increased in particular for Austria, Greece and Portugal. Also the share of high-skilled nonproduction occupations increased for these countries as well as for Luxembourg, Slovenia and Italy. ${ }^{4}$ In many NMS countries the increase has been less than the EU15 average. The degree of, skills upgrading measured by the non-production occupations has been strong in Poland relative to the other NMS countries. The same holds for Slovenia with respect the high-skilled nonproduction workers. This implies that Greece, Portugal and Poland are catching up with the EU15 average as to their skill structure. Only in three out of 25 countries the shares of non-production or high-skilled non-production workers have decreased.

The decomposition analysis indicates that the within effect contributes most to the change in the share of high-skilled non-production employment (last column in Table 4). The cross-country average share of the within effect in the total change is 71\% (in EU15 71\% and in NMS10 72\%, the six countries with a negative within effect are excluded). This is consistent with most of the literature on skill-biased technological change; see for instance Berman et al. (1998) for developed countries, and Berman et al. (2000) and Kang (2002) for developing countries. For example, Berman et al. (1998) estimated the within effect of the change in the share of nonproduction workers to be $84 \%$ in the 1970 s, and $92 \%$ in the 1980 s in selected OECD countries. Most of the literature in this field proceeds from the production/non-production division. In the current analysis, the within effect accounts for $58 \%$ of the change in the share of non-production employment in EU25 countries (again, the five countries with a negative within effect are excluded) (see the last column in Table 3). For the NMS10 group the importance of within effect is a bit higher, accounting for $64 \%$ of the change, while the within effect accounts for $54 \%$ of the

\footnotetext{
${ }^{4}$ The large growth of high-skilled non-production occupations in Italy is probably to a large extent due to a major revision in classifying workers into high-skill occupations in the Italian survey.
} 
change in the EU15 countries. This may indicate the decreasing role of skill-biased technological change in skills upgrading for a wider group of skilled workers.

Table 3. Share of non-production occupations in the EU in 2000 - 2004.

\begin{tabular}{|c|c|c|c|c|c|c|c|}
\hline \multirow[b]{2}{*}{ Belgium (BE) } & \multirow{2}{*}{$\begin{array}{c}\text { Share in. } \\
2000 \\
0.681\end{array}$} & \multirow{2}{*}{$\begin{array}{c}\text { Share in } \\
2004\end{array}$} & \multirow{2}{*}{$\begin{array}{c}\text { Difference in } \\
\text { the share } \\
2000-2004 \\
0.009\end{array}$} & \multicolumn{2}{|c|}{$\begin{array}{c}\text { Between effect } \\
\text { (size and } \\
\text { share, \%) }\end{array}$} & \multicolumn{2}{|c|}{$\begin{array}{l}\text { Within effect } \\
\text { (size and } \\
\text { share, \%) }\end{array}$} \\
\hline & & & & 0.002 & 26 & 0.007 & 74 \\
\hline Austria (AT) & 0.601 & 0.656 & 0.055 & 0.022 & 41 & 0.033 & 59 \\
\hline Denmark (DK) & 0.672 & 0.676 & 0.004 & 0.009 & 225 & -0.005 & -125 \\
\hline Finland (FI) & 0.650 & 0.658 & 0.008 & 0.018 & 225 & -0.010 & -125 \\
\hline France (FR) & 0.631 & 0.638 & 0.007 & 0.006 & 91 & 0.001 & 9 \\
\hline Germany (DE) & 0.643 & 0.669 & 0.026 & 0.014 & 55 & 0.012 & 45 \\
\hline Greece (EL) & 0.531 & 0.580 & 0.048 & 0.039 & 79 & 0.010 & 21 \\
\hline Ireland (IE) & 0.668 & 0.694 & 0.026 & 0.002 & 10 & 0.024 & 90 \\
\hline Italy (IT) & 0.606 & 0.620 & 0.014 & 0.006 & 46 & 0.008 & 54 \\
\hline Luxembourg (LU) & 0.652 & 0.683 & 0.031 & 0.004 & 13 & 0.027 & 87 \\
\hline Netherlands (NL) & 0.730 & 0.743 & 0.013 & 0.007 & 52 & 0.006 & 48 \\
\hline Portugal (PT) & 0.444 & 0.492 & 0.048 & 0.021 & 44 & 0.027 & 56 \\
\hline Spain (ES) & 0.533 & 0.545 & 0.012 & 0.005 & 41 & 0.007 & 59 \\
\hline Sweden (SW) & 0.700 & 0.723 & 0.023 & 0.012 & 54 & 0.011 & 46 \\
\hline UK (UK) & 0.721 & 0.717 & -0.004 & 0.013 & 325 & -0.017 & -425 \\
\hline Czech Republic (CZ) & 0.557 & 0.578 & 0.021 & 0.009 & 43 & 0.012 & 57 \\
\hline Cyprus (CY) & 0.590 & 0.585 & -0.005 & -0.013 & -260 & 0.008 & 160 \\
\hline Estonia (EE) & 0.543 & 0.557 & 0.012 & 0.011 & 90 & 0.001 & 10 \\
\hline Hungary (HU) & 0.551 & 0.571 & 0.020 & 0.013 & 65 & 0.007 & 35 \\
\hline Latvia (LV) & 0.525 & 0.539 & 0.014 & -0.001 & -7 & 0.015 & 107 \\
\hline Lithuania (LT) & 0.478 & 0.475 & -0.003 & 0.010 & 333 & -0.013 & -433 \\
\hline Malta (MT) & 0.593 & 0.605 & 0.011 & 0.015 & 136 & -0.004 & -36 \\
\hline Poland (PL) & 0.479 & 0.506 & 0.027 & 0.020 & 73 & 0.007 & 27 \\
\hline Slovakia (SK) & 0.546 & 0.556 & 0.010 & 0.005 & 50 & 0.005 & 50 \\
\hline Slovenia (SI) & 0.550 & 0.565 & 0.014 & 0.005 & 36 & 0.009 & 64 \\
\hline EU15 average $^{*}$ & 0.636 & 0.650 & 0.014 & 0.011 & 78 & 0.003 & 22 \\
\hline NMS10 average & 0.512 & 0.534 & 0.022 & 0.016 & 72 & 0.006 & 28 \\
\hline EU25 average & 0.617 & 0.633 & 0.016 & 0.012 & 76 & 0.004 & 24 \\
\hline
\end{tabular}

* Weighted average based on employment volumes.

Source: Labour Force Surveys from 25 EU countries, authors’ calculations. 
Table 4. Share of high-skilled non-production occupations in the EU in 2000 - 2004.

\begin{tabular}{|c|c|c|c|c|c|c|c|}
\hline \multirow[b]{2}{*}{ Belgium (BE) } & \multirow{2}{*}{$\begin{array}{c}\text { Share in. } \\
2000\end{array}$} & \multirow{2}{*}{$\begin{array}{c}\text { Share in } \\
2004\end{array}$} & \multirow{2}{*}{$\begin{array}{c}\begin{array}{c}\text { Difference in } \\
\text { the share } \\
2000-2004\end{array} \\
0.018\end{array}$} & \multicolumn{2}{|c|}{$\begin{array}{c}\text { Between effect } \\
\text { (size and } \\
\text { share, \%) }\end{array}$} & \multicolumn{2}{|c|}{$\begin{array}{c}\text { Within effect } \\
\text { (size and } \\
\text { share, \%) }\end{array}$} \\
\hline & & & & 0.004 & 25 & 0.014 & 75 \\
\hline Austria (AT) & 0.318 & 0.387 & 0.069 & 0.013 & 20 & 0.056 & 80 \\
\hline Denmark (DK) & 0.408 & 0.427 & 0.019 & 0.004 & 23 & 0.015 & 77 \\
\hline Finland (FI) & 0.446 & 0.427 & -0.019 & 0.011 & 58 & -0.030 & -158 \\
\hline France (FR) & 0.360 & 0.384 & 0.024 & 0.0007 & 3 & 0.023 & 97 \\
\hline Germany (DE) & 0.396 & 0.421 & 0.025 & 0.012 & 47 & 0.013 & 53 \\
\hline Greece (EL) & 0.286 & 0.326 & 0.040 & 0.029 & 73 & 0.011 & 27 \\
\hline Ireland (IE) & 0.381 & 0.412 & 0.031 & -0.003 & -10 & 0.034 & 110 \\
\hline Italy (IT) & 0.311 & 0.395 & 0.084 & 0.010 & 13 & 0.074 & 87 \\
\hline $\begin{array}{l}\text { Luxembourg } \\
\text { (LU) }\end{array}$ & 0.401 & 0.454 & 0.053 & 0.010 & 19 & 0.043 & 81 \\
\hline $\begin{array}{l}\text { Netherlands } \\
(\mathrm{NL})\end{array}$ & 0.481 & 0.486 & 0.005 & 0.007 & 140 & -0.002 & -40 \\
\hline Portugal (PT) & 0.214 & 0.261 & 0.047 & 0.012 & 26 & 0.035 & 74 \\
\hline Spain (ES) & 0.291 & 0.309 & 0.018 & 0.004 & 25 & 0.014 & 75 \\
\hline Sweden (SW) & 0.417 & 0.440 & 0.023 & 0.020 & 84 & 0.003 & 16 \\
\hline UK (UK) & 0.403 & 0.406 & 0.003 & 0.004 & 133 & -0.001 & -33 \\
\hline $\begin{array}{l}\text { Czech Republic } \\
\text { (CZ) }\end{array}$ & 0.358 & 0.375 & 0.017 & 0.003 & 19 & 0.014 & 81 \\
\hline Cyprus (CY) & 0.267 & 0.284 & 0.017 & 0.002 & 13 & 0.015 & 87 \\
\hline Estonia (EE) & 0.387 & 0.384 & -0.003 & 0.008 & 267 & -0.011 & -367 \\
\hline Hungary (HU) & 0.322 & 0.341 & 0.019 & 0.010 & 54 & 0.009 & 46 \\
\hline Latvia (LV) & 0.343 & 0.333 & -0.010 & -0.002 & -24 & -0.008 & -76 \\
\hline Lithuania (LT) & 0.305 & 0.323 & 0.018 & 0.001 & 7 & 0.017 & 93 \\
\hline Malta (MT) & 0.331 & 0.335 & 0.004 & 0.009 & 225 & -0.005 & -125 \\
\hline Poland (PL) & 0.296 & 0.317 & 0.021 & 0.012 & 59 & 0.009 & 41 \\
\hline Slovakia (SK) & 0.342 & 0.353 & 0.011 & 0.003 & 28 & 0.008 & 72 \\
\hline Slovenia (SI) & 0.319 & 0.360 & 0.041 & 0.006 & 14 & 0.035 & 86 \\
\hline EU15 average ${ }^{*}$ & 0.366 & 0.393 & 0.027 & 0.008 & 28 & 0.019 & 72 \\
\hline NMS10 average & 0.317 & 0.336 & 0.019 & 0.010 & 52 & 0.009 & 48 \\
\hline EU25 average* & 0.358 & 0.384 & 0.026 & 0.008 & 32 & 0.017 & 68 \\
\hline
\end{tabular}

${ }^{*}$ Weighted average based on employment volumes.

Source: Labour Force Surveys from 25 EU countries, authors’ calculations.

The decomposed between industry and within industry effects are also mapped in Figures 3 and 4. The picture is clear in the sense that most of the countries have experienced skills upgrading due to both skill favouring industry and within industry shifts (most of the observations lie in the upper right section of the Figures 3 and 4). This pattern is more evident under the narrower definition of skills, i.e. for high-skilled non-production workers. Within industry developments have clearly a stronger impact on skills upgrading for high-skilled non-production employment shares (notice the scaling of the horizontal axis of the Figures 3 and 4). A comparison of country groups does not provide a particular pattern, although NMS10 group tends to have effects of a smaller magnitude (situated closer to the origin). 


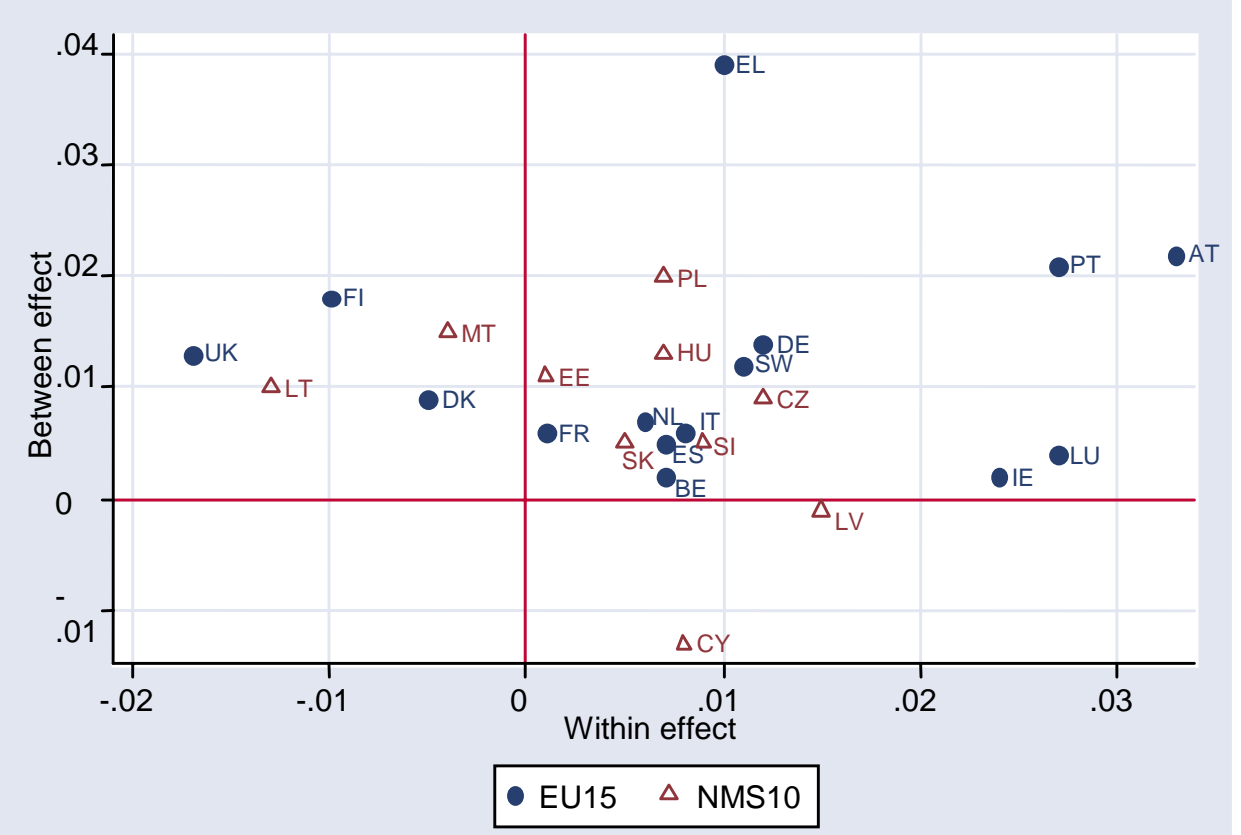

Source: Labour Force Surveys from 25 EU countries, authors' calculations.

Figure 3. Between and within effects of the employment shares of non-production occupations, 2000-2004.

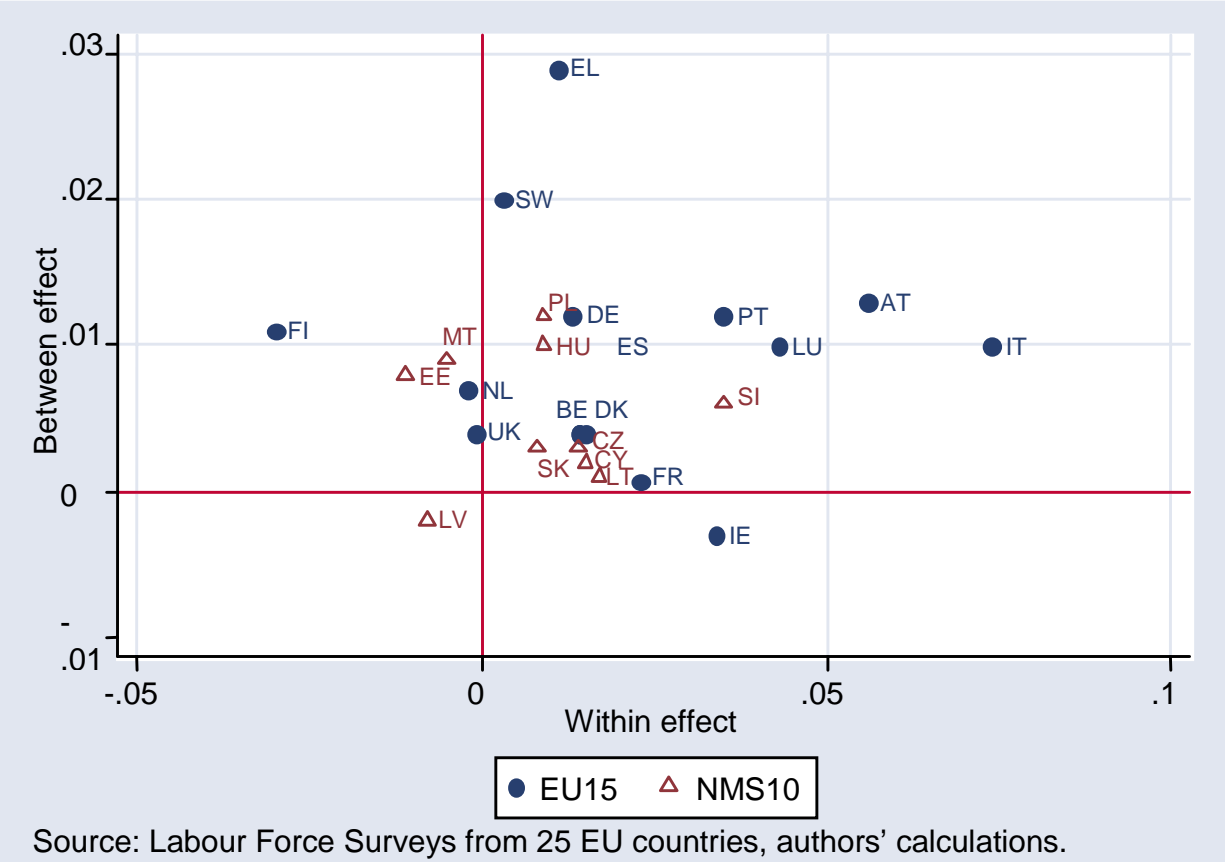

Figure 4. Between and within effects of the employment shares of high-skilled non-production occupations, 2000-2004. 


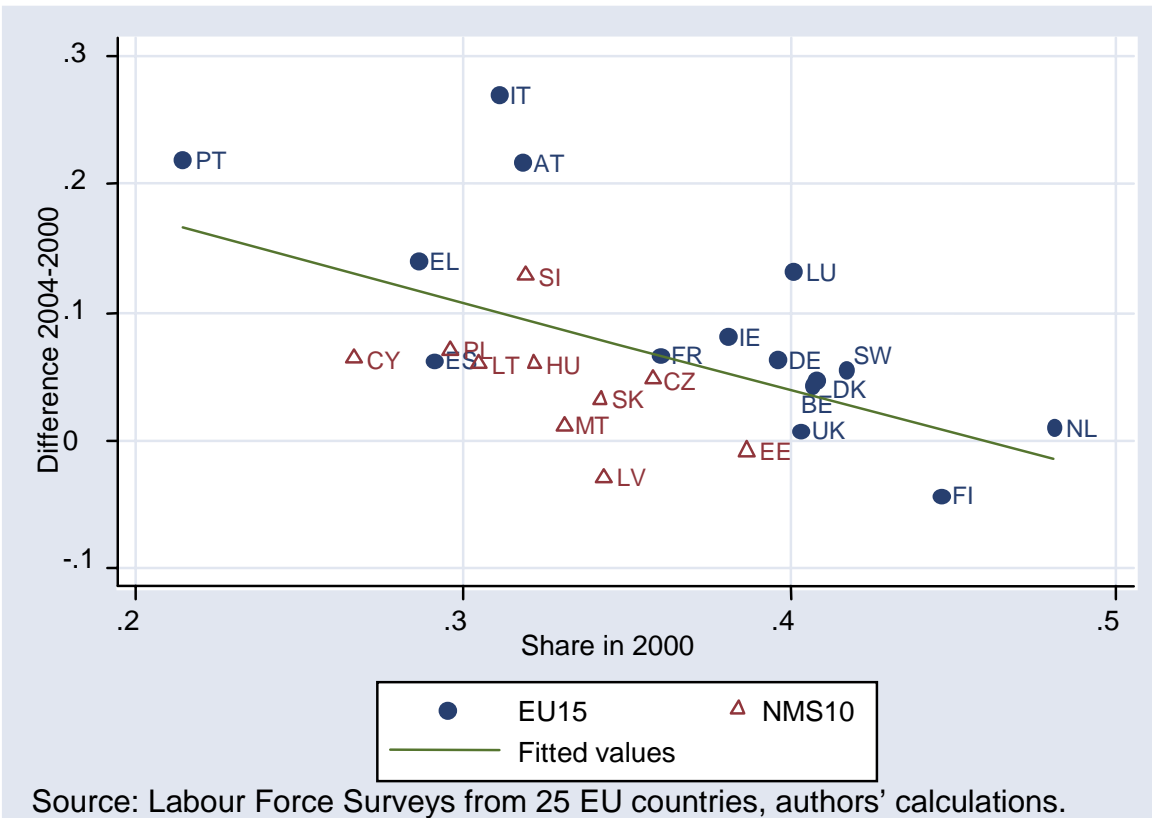

Figure 5. The share of high-skilled non-production occupations in 2000 and the differences over 2000-2004.

Figure 5 shows that for the high-skilled non-production occupations, the initial level in 2000 and the difference over time are significantly correlated. This suggests that convergence has taken place among the EU25 countries: the countries with a higher share of skilled occupations have a lower increase in the relative demand for skills. This, however, is not the case for the share of non-production employment. The results indicate a diffusion of increased skill demand within industries across countries and convergence of the share of high-skilled non-production employment.

\subsection{Technology diffusion in the EU}

An additional exercise for testing the pervasiveness of skills upgrading across countries is by testing for skills upgrading within the same production sectors across countries. Technology is often presumed to be a public good, which is expected to spread quickly from country to country. If skills upgrading is really the result of skill-biased technological change, one should observe within-industry skills upgrading in similar industries across countries. In this respect, the European Union is a good example for analysis; although the countries' levels of development vary, they have similar institutional environments, and also trade intensively with each other within a close geographical range.

Berman et al. (1998) showed the existence of skills upgrading in similar industries among developed OECD countries. They observed that the within effects of the change in nonproduction employment of different industries were tightly and positively correlated across eight OECD countries. They interpreted this result as an indication of technology diffusion across countries. Berman et al. (1998) observed 33 out of 36 positive correlations and 11 out of 36 positive statistically significant correlations at the $5 \%$ level. Extending the same exercise to 
developing countries revealed similar results in within industry skill shifts between developed and middle-income countries, but not between developed and low-income countries (Berman and Machin (2000)). A similar approach is used in this paper. We undertake the analysis for two country groups: (1) the more developed group of countries defined as the EU12, which consists of the EU15, excluding Greece, Portugal and Spain, and (2) all EU25 countries.

Table 5 presents the correlations between individual countries within industry shifts in nonproduction workers. Again the number of industries used is 18 (see appendix B). Similarly to Berman et al. (1998), the within effects of all countries are found by multiplying each country's within sector skills upgrading by the over-time average of European average employment shares (in the second term of equation 5 , the $\bar{s}_{i}$ is now not just the country's over-time average, but the over-time average of the European cross-country average). The purpose of this weighting is to ensure cross-country comparison of the countries' within effects by eliminating the impact of the country-specific industry structure.

Our results for the EU12 countries indicate that for the non-production employment share, 55 out of 66 correlations are positive and 20 out of 66 correlations are positive and significant at the $5 \%$ level (see Table 5). For example, Belgium's within-industry skill shifts correlate at the 5\% level with within industry shifts in Austria. The respective numbers for the high-skilled non-production employment shares are 45 out of 66 and 15 out of 66 (see Table 6). Now the correlation coefficient between Belgium and Austria within industry skills upgrading is still high, but insignificant at 5\% level. For the EU25 countries, the relative number of positive and significant correlations is lower, namely 205 out of 300, and 54 out of 300 for the non-production employment share, and 188 out of 300 and 61 out of 300 for the high-skilled non-production employment share.

Berman and Machin (2000) found that 31\% of the within industry shifts in skills demand are positively and significantly correlated in selected OECD countries. Our results show this share to be $30 \%$ for the EU12 countries' non-production employment. Hence, skills upgrading or technology diffusion appears to be pervasive for the most developed EU countries. As expected, for a wider group of countries, the shifts in skill use within industries are less correlated indicating lower technology diffusion.

A shortcoming of the shift-share methodology, as used also in this paper, is pointed out by Berman et al. (1998, pp. 1260-1262). They argue that the assumption of homogeneous products within industries is questionable at a high aggregation level of industries. There is a danger of interpreting the within industry shift from the production of low-skill intensive products to highskill intensive products as skill-biased technological change. However, they find that their estimations of the within effects of 28 manufacturing industries did not differ much from the estimations using plant-level data. The lack of more disaggregated data for all countries does not allow us to test whether the results differ for more disaggregated or firm-level data. This may be an important point for further research, since Berman et al., 1994) show that there may be some overestimation of the within effect at the more aggregated level. 
Table 5. Correlations ${ }^{(1)} *$ of within industry shifts in non-production employment shares, EU12 and EU25, 2000-2004

\begin{tabular}{|c|c|c|c|c|c|c|c|c|c|c|c|c|c|c|c|c|c|c|c|c|c|c|c|c|c|}
\hline & $\mathrm{BE}$ & $\mathrm{AT}$ & DK & FI & FR & $\mathrm{DE}$ & IE & IT & LU & NL & $\mathrm{SE}$ & UK & EL & PT & ES & $\mathrm{CZ}$ & CY & $\mathrm{EE}$ & $\mathrm{HU}$ & LV & LT & MT & PL & SK & SI \\
\hline $\mathrm{BE}^{(2)}$ & 1 & & & & & & & & & & & & & & & & & & & & & & & & \\
\hline AT & 0.51 & 1 & & & & & & & & & & & & & & & & & & & & & & & \\
\hline DK & 0.25 & 0.50 & 1 & & & & & & & & & & & & & & & & & & & & & & \\
\hline FI & 0.21 & 0.60 & 0.60 & 1 & & & & & & & & & & & & & & & & & & & & & \\
\hline FR & -0.08 & 0.46 & 0.34 & 0.63 & 1 & & & & & & & & & & & & & & & & & & & & \\
\hline $\mathrm{DE}$ & 0.44 & 0.78 & 0.55 & 0.73 & 0.66 & 1 & & & & & & & & & & & & & & & & & & & \\
\hline IE & 0.18 & 0.75 & 0.66 & 0.69 & 0.79 & 0.87 & 1 & & & & & & & & & & & & & & & & & & \\
\hline IT & -0.37 & -0.25 & 0.10 & 0.00 & 0.35 & 0.02 & 0.19 & 1 & & & & & & & & & & & & & & & & & \\
\hline LU & -0.21 & 0.06 & 0.22 & 0.16 & 0.38 & 0.29 & 0.38 & 0.72 & 1 & & & & & & & & & & & & & & & & \\
\hline NL & 0.15 & 0.73 & 0.62 & 0.65 & 0.45 & 0.79 & 0.83 & -0.02 & 0.23 & 1 & & & & & & & & & & & & & & & \\
\hline SE & -0.20 & -0.07 & 0.41 & 0.35 & 0.28 & 0.15 & 0.11 & 0.25 & 0.12 & 0.08 & 1 & & & & & & & & & & & & & & \\
\hline UK & 0.43 & 0.40 & 0.45 & 0.40 & -0.22 & 0.30 & 0.23 & -0.57 & -0.25 & 0.44 & -0.11 & 1 & & & & & & & & & & & & & \\
\hline$\overline{\mathrm{EL}}$ & -0.22 & 0.32 & 0.45 & 0.21 & 0.53 & 0.45 & 0.69 & 0.32 & 0.32 & 0.61 & 0.33 & 0.03 & 1 & & & & & & & & & & & & \\
\hline PT & 0.04 & 0.33 & 0.24 & -0.02 & 0.45 & 0.43 & 0.55 & 0.32 & 0.28 & 0.39 & 0.22 & -0.16 & 0.86 & 1 & & & & & & & & & & & \\
\hline ES & 0.05 & 0.61 & 0.26 & 0.37 & 0.51 & 0.67 & 0.67 & 0.07 & 0.35 & 0.72 & 0.00 & -0.02 & 0.61 & 0.61 & 1 & & & & & & & & & & \\
\hline CZ & -0.03 & 0.41 & 0.40 & 0.40 & 0.49 & 0.45 & 0.44 & -0.08 & 0.19 & 0.51 & 0.52 & 0.01 & 0.49 & 0.41 & 0.62 & 1 & & & & & & & & & \\
\hline CY & -0.17 & 0.43 & 0.26 & 0.51 & 0.70 & 0.64 & 0.77 & 0.04 & 0.11 & 0.75 & 0.07 & 0.16 & 0.73 & 0.50 & 0.62 & 0.44 & 1 & & & & & & & & \\
\hline EE & -0.33 & 0.15 & 0.47 & 0.30 & 0.03 & 0.13 & 0.25 & 0.13 & 0.01 & 0.40 & 0.10 & 0.26 & 0.21 & -0.02 & 0.12 & -0.07 & 0.19 & 1 & & & & & & & \\
\hline $\mathrm{HU}$ & -0.13 & 0.37 & 0.32 & 0.00 & 0.21 & 0.22 & 0.46 & 0.22 & 0.36 & 0.45 & 0.04 & 0.17 & 0.75 & 0.72 & 0.52 & 0.37 & 0.35 & 0.21 & 1 & & & & & & \\
\hline LV & -0.27 & -0.38 & 0.08 & -0.01 & 0.39 & 0.03 & 0.17 & 0.52 & 0.34 & -0.23 & 0.26 & -0.25 & 0.32 & 0.28 & -0.18 & -0.22 & 0.19 & 0.00 & -0.03 & 1 & & & & & \\
\hline LT & 0.12 & -0.27 & 0.04 & -0.32 & -0.55 & -0.37 & -0.38 & -0.39 & -0.16 & -0.24 & -0.19 & 0.45 & -0.35 & -0.39 & -0.46 & -0.07 & -0.41 & -0.12 & 0.01 & -0.21 & 1 & & & & \\
\hline MT & -0.30 & -0.30 & 0.11 & 0.17 & 0.17 & 0.07 & 0.19 & 0.09 & 0.03 & 0.29 & -0.04 & 0.16 & 0.27 & -0.01 & 0.13 & 0.11 & 0.54 & 0.18 & -0.03 & 0.29 & 0.12 & 1 & & & \\
\hline PL & -0.16 & -0.64 & -0.51 & -0.70 & -0.33 & -0.53 & -0.49 & 0.08 & 0.02 & -0.59 & -0.05 & -0.29 & -0.08 & 0.05 & -0.42 & -0.19 & -0.29 & -0.64 & -0.01 & 0.26 & 0.46 & 0.07 & 1 & & \\
\hline SK & 0.15 & -0.39 & -0.17 & -0.13 & -0.26 & -0.05 & -0.29 & -0.20 & -0.07 & -0.15 & -0.02 & -0.07 & -0.36 & -0.37 & -0.09 & -0.01 & -0.14 & -0.37 & -0.66 & 0.00 & 0.19 & 0.36 & 0.26 & 1 & \\
\hline SI & -0.16 & -0.34 & 0.07 & -0.22 & -0.18 & -0.17 & -0.18 & -0.11 & 0.14 & -0.10 & 0.43 & 0.05 & 0.19 & 0.12 & 0.03 & 0.49 & -0.08 & -0.32 & 0.15 & 0.06 & 0.49 & 0.25 & 0.55 & 0.44 & 1 \\
\hline
\end{tabular}

(1) Correlation coefficients in bold print reflect statistical significance at $5 \%$ level.

(2) For country abbreviations, see Tables 1, 2, 3 or 4 .

Source: Labour Force Surveys from 25 EU countries, authors' calculations. 
Table 6. Correlations* of within industry shifts in high-skilled non-production employment shares, EU12 and EU25, 2000-2004

\begin{tabular}{|c|c|c|c|c|c|c|c|c|c|c|c|c|c|c|c|c|c|c|c|c|c|c|c|c|c|}
\hline & $\mathrm{BE}$ & AT & DK & FI & FR & DE & IE & IT & LU & NL & SE & UK & EL & PT & ES & $\mathrm{CZ}$ & CY & EE & $\mathrm{HU}$ & LV & LT & MT & PL & SK & SI \\
\hline $\mathrm{BE}^{(2)}$ & 1 & & & & & & & & & & & & & & & & & & & & & & & & \\
\hline AT & 0.31 & 1 & & & & & & & & & & & & & & & & & & & & & & & \\
\hline DK & -0.04 & 0.17 & 1 & & & & & & & & & & & & & & & & & & & & & & \\
\hline FI & 0.45 & 0.52 & -0.11 & 1 & & & & & & & & & & & & & & & & & & & & & \\
\hline FR & 0.34 & 0.66 & 0.35 & 0.55 & 1 & & & & & & & & & & & & & & & & & & & & \\
\hline $\mathrm{DE}$ & 0.45 & 0.57 & 0.56 & 0.30 & 0.84 & 1 & & & & & & & & & & & & & & & & & & & \\
\hline IE & 0.41 & 0.63 & 0.26 & 0.41 & 0.81 & 0.85 & 1 & & & & & & & & & & & & & & & & & & \\
\hline IT & 0.06 & -0.08 & -0.42 & -0.38 & -0.35 & -0.39 & -0.48 & 1 & & & & & & & & & & & & & & & & & \\
\hline LU & -0.27 & 0.12 & 0.26 & 0.19 & 0.31 & 0.26 & 0.16 & -0.50 & 1 & & & & & & & & & & & & & & & & \\
\hline NL & 0.29 & -0.37 & -0.45 & -0.01 & -0.24 & -0.07 & 0.19 & -0.10 & -0.30 & 1 & & & & & & & & & & & & & & & \\
\hline SE & 0.13 & -0.02 & 0.21 & 0.18 & 0.08 & 0.14 & 0.22 & -0.53 & 0.24 & 0.03 & 1 & & & & & & & & & & & & & & \\
\hline UK & 0.66 & 0.62 & 0.02 & 0.70 & 0.58 & 0.49 & 0.62 & -0.16 & -0.28 & 0.12 & 0.20 & 1 & & & & & & & & & & & & & \\
\hline EL & -0.20 & -0.07 & 0.61 & -0.33 & 0.28 & 0.53 & 0.50 & -0.55 & 0.17 & 0.16 & 0.13 & -0.09 & 1 & & & & & & & & & & & & \\
\hline PT & 0.11 & 0.42 & 0.59 & 0.04 & 0.59 & 0.72 & 0.53 & -0.37 & 0.45 & -0.36 & 0.17 & 0.24 & 0.47 & 1 & & & & & & & & & & & \\
\hline ES & 0.62 & 0.31 & -0.05 & 0.59 & 0.64 & 0.59 & 0.71 & -0.42 & 0.20 & 0.33 & 0.36 & 0.54 & 0.15 & 0.15 & 1 & & & & & & & & & & \\
\hline CZ & -0.03 & 0.74 & 0.38 & 0.44 & 0.67 & 0.53 & 0.53 & -0.24 & 0.29 & -0.35 & -0.20 & 0.36 & 0.24 & 0.28 & 0.25 & 1 & & & & & & & & & \\
\hline CY & 0.49 & 0.56 & 0.12 & 0.38 & 0.57 & 0.62 & 0.66 & -0.06 & -0.05 & 0.07 & 0.37 & 0.71 & 0.07 & 0.27 & 0.54 & 0.35 & 1 & & & & & & & & \\
\hline $\mathrm{EE}$ & -0.09 & 0.27 & -0.16 & 0.56 & 0.09 & 0.06 & 0.09 & -0.36 & 0.54 & 0.09 & -0.02 & 0.12 & -0.17 & 0.01 & 0.16 & 0.38 & 0.09 & 1 & & & & & & & \\
\hline $\mathrm{HU}$ & 0.60 & 0.51 & 0.02 & 0.72 & 0.62 & 0.51 & 0.58 & -0.12 & 0.11 & 0.17 & 0.18 & 0.69 & -0.15 & 0.07 & 0.66 & 0.46 & 0.69 & 0.30 & 1 & & & & & & \\
\hline LV & 0.20 & -0.44 & -0.32 & 0.28 & 0.15 & -0.09 & 0.08 & -0.14 & -0.14 & 0.47 & 0.20 & 0.17 & -0.04 & -0.29 & 0.42 & -0.31 & 0.01 & -0.21 & 0.29 & 1 & & & & & \\
\hline LT & -0.26 & -0.10 & 0.78 & -0.55 & -0.08 & 0.15 & -0.17 & 0.05 & 0.05 & -0.47 & 0.05 & -0.36 & 0.44 & 0.23 & -0.39 & 0.16 & -0.10 & -0.40 & -0.26 & -0.43 & 1 & & & & \\
\hline MT & 0.22 & -0.40 & -0.28 & 0.47 & -0.08 & -0.26 & -0.22 & -0.11 & 0.00 & 0.34 & 0.09 & 0.12 & -0.33 & -0.54 & 0.32 & -0.15 & -0.03 & 0.22 & 0.39 & 0.68 & -0.34 & 1 & & & \\
\hline PL & -0.21 & -0.34 & 0.58 & -0.51 & -0.23 & -0.02 & -0.16 & -0.07 & -0.17 & -0.16 & 0.27 & -0.34 & 0.44 & -0.06 & -0.28 & -0.13 & -0.13 & -0.55 & -0.25 & -0.02 & 0.81 & -0.12 & 1 & & \\
\hline SK & 0.38 & -0.03 & -0.16 & 0.65 & 0.45 & 0.14 & 0.16 & -0.13 & 0.14 & 0.07 & 0.19 & 0.43 & -0.31 & -0.03 & 0.55 & -0.01 & 0.24 & 0.09 & 0.61 & 0.74 & -0.43 & 0.72 & -0.31 & 1 & \\
\hline SI & 0.00 & 0.01 & 0.38 & -0.26 & 0.24 & 0.36 & -0.04 & 0.23 & 0.21 & -0.42 & -0.17 & -0.13 & 0.22 & 0.34 & 0.01 & 0.23 & 0.19 & -0.11 & -0.09 & -0.27 & 0.51 & -0.16 & 0.19 & -0.06 & 1 \\
\hline
\end{tabular}

${ }^{(1)}$ Correlation coefficients in bold print reflect statistical significance at $5 \%$ level.

(2) For country abbreviations, see Tables 1, 2, 3 or 4.

Source: Labour Force Surveys from 25 EU countries, authors’ calculations. 
On several occasions, the positive within industry effect, in spite of increasing relative wages, could be the result of some other factors than SBTC (Berman et al. 1998, pp. 1260-1262):

- Skills upgrading could be the result of capital investments with complementary shifts to highskilled labour.

- Plant-level demand increases in skill-intensive goods. In high-income countries this could be the result of increased openness to non-skill-intensive goods from developing countries, which increases the relative price of skill-intensive goods.

- Plant-level outsourcing of low-skilled occupations. Berman et al. (1998) estimate that in the USA, outsourcing could account at most for $16 \%$ of the decrease in unskilled workers between 1973 and 1987.

There may be factors other than skill-biased technological change driving skills upgrading in the developed world, with outsourcing as a prime possibility. Geishecker (2006, p. 580) estimates for Germany that outsourcing to Central and Eastern European countries is an important factor that decreases the demand for production workers in Germany, while technological change is still the most important factor, but to a somewhat lesser extent.

\section{Summary}

In this paper, we employed Labour Force Survey data for the EU25 countries to decompose the shifts in the countries' occupational structures into the within industry and between industries effects. We carried out two types of analyses: a static analysis for the year 2004, and a dynamic analysis for the period 2000-2004. Both of these analyses were implemented proceeding from two different definitions of skilled workers: the employment share of non-production workers, and the employment share of high-skilled non-production workers.

The main conclusion is that the old Member States, except Greece, Portugal and Spain, are characterized by a more skill-intensive occupational structure than the new Member States. This is the case irrespective of whether skill intensiveness is measured by the share of non-production workers or by the share of high-skilled non-production workers. In 2004, the EU15 countries (except Greece, Portugal and Spain) used more skilled workers because of both the industrial (between) and the technological (within) effects. This implies that these countries have a more skill-intensive industry structure and their production technology within industries is more intensively based on skills, while the new member countries' (except Malta's) industry structure is clearly biased towards less skill-intensive industries. In general, the differences in the shares of (high-skilled) non-production workers between countries are dominated by the between (industrial) effect.

The dynamic analysis of 2000-2004 showed that changes in the share of high-skilled nonproduction workers are mostly driven by within-sector changes, which are probably related to skill-biased technological change. Also, the developments in the share of the total group of nonproduction workers are larger for the within (technology) than for the between (industrial) effect, although less evidently than for the high-skilled non-production workers in our study and the non-production workers in the study by Berman et al. (1998). These results could also indicate 
the slowdown of the implications of skill-biased technological change for non-production vs. production composition of the workforce.

The diffusion of the increased demand for skills within sectors has been witnessed for the EU12 country group, but less strongly for the EU25 country group. Overall, the convergence of the share of high-skilled non-production workers is apparent. The differences in skill use between the new and old Member States can mostly be accounted for by differences in their industry structures. Similar trends in the countries' within effects support the idea that skill demand in the new member countries is catching up, while the structural developments that could equalize the industry mix of the new and old member countries are related to increased domestic demand and will probably take time.

The shift-share analysis of this paper can be used to forecast the employment growth of occupations in the EU Member States. If forecasts of the countries' sector employment levels are made, for instance, by means of a macroeconomic forecasting model, the between effect represents the impact of the predicted changes in the industry composition on the occupational structure within countries. Moreover, changes of the occupational mix within sectors follow from the within effect. This effect can be predicted by extrapolating the time trends of skills upgrading within sectors of industry. If possible, the occupational upgrading should be related to exogenous variables that can explain the extent of occupational upgrading. ${ }^{5}$

Data availability implied that we proceeded only from the occupational structure. An alternative measure of the skill structure can be obtained from data on educational attainment. ${ }^{6}$ An interesting avenue of future research would be a comparative analysis of information on occupational structure and educational attainment.

\section{Acknowledgement}

We would like to thank Karsten Staehr, Aurelijus Dabusinskas, Tiiu Paas, Arnaud Dupuy, Andries de Grip and the anonymous referee for their helpful comments. We have also benefited from comments by the participants of the seminar at the University of Tartu Faculty of Economics and Business Administration on 25 Oct. 2006, the CEDEFOP workshop “Anticipating Europe's skill needs” at the University of Warwick on 2-3 Nov. 2006, the U-know project meeting at the University of Sussex on $7-10$ Nov. 2006, and the annual meeting of the Estonian Economic Society in Pärnu on 12-13 Jan. 2007. Jaanika Meriküll acknowledges financial support from the grant of Jüri Sepp, RMJRISEPP and from the Sixth EU Framework Programme project CIT5-CT-028519. The authors alone are responsible for any remaining errors and inconsistencies.

\footnotetext{
${ }^{5}$ See e.g. Dekker et al. (1990) and Cörvers and Dupuy (2006) for the Netherlands, and Briscoe and Wilson (2003) for the UK.

${ }^{6}$ See Winchester et al. (2006) for a comparison of these two approaches and the implementation of cluster analysis to combine wage and educational information of occupational groups with the aim of deriving a composite measure of skills.
} 


\section{References}

Autor, David, H.; Katz, Lawrence, F.; Krueger, Alan, B (1998) Computing Inequality: Have Computers Changed the Labor Market? The Quarterly Journal of Economics 113: 1169-1213.

Baltagi, Badi, H.; Rich, Daniel, P. (2006) Skill-biased technical change in US manufacturing: a general index approach. Journal of Econometrics 126: 549-570.

Barrell, Ray; Pain, Nigel (1997) Foreign Direct Investment, Technological Change, and Economic Growth within Europe. The Economic Journal 107: 1770-86.

Berman, Eli; Bound, John; Griliches, Zvi (1994) Changes in the Demand for Skilled Labor within U.S. Manufacturing: Evidence from the Annual Survey of Manufacturers. The Quarterly Journal of Economics 109: 367-397.

Berman, Eli; Bound, John; Machin, Stephen (1998) Implications of Skill-Biased Technological Change: International Evidence. The Quarterly Journal of Economics 113: 1245-1279.

Berman, Eli; Machin, Stephen (2000) Skill-Biased Technology Transfer around the World. Oxford Review of Economic Policy 16: 12-22.

Blanke, Jennifer (2006) The Lisbon Review 2006: Measuring Europe's Progress in Reform. World Economic Forum, Geneva. http://www.weforum.org/pdf/gcr/lisbonreview/report2006.pdf. Cited 5 Nov 2007

Caroli, Eve; Van Reenen, John (2001) Skill-biased organizational change? Evidence from a panel of British and French establishments. The Quarterly Journal of Economics 116: 1449-1492.

Cörvers, Frank; Dupuy, Arnaud (2006). Explaining the Occupational Structure of Dutch Sectors of Industry, 1988-2003. ROA Working Paper No. 2006/7E. http://www.roa.unimaas.nl/pdf\%20publications/2006/ROA-W-2006_7E.pdf. Cited 5 Nov 2007

Dekker, Ron; Grip, Andries de; Heijke, Hans (1990) An Explanation of the Occupational Structure of Sectors of Industry. Labour 4: 3-31.

Edwards, Lawrence (2004) A Firm Level Analysis of Trade, Technology and Employment in South Africa. Journal of International Development 16: 45-61.

Elias, Peter; McNight, Abigail (2001) Skill Measurement in Official Statistics: Recent Developments in the UK and the Rest of Europe. Oxford Economic Papers 53: 508-40.

Esteban, Joan (2000) Regional Convergence in Europe and the Industry Mix: A Shift-Share Analysis. Regional Science and Urban Economics 30: 353-64.

European Commission (2003a) Employment in Europe 2003 - Recent Trends and Prospects. Luxembourg: Office for Official Publication of the European Communities. http://ec.europa.eu/employment_social/employment_analysis/employ_2003_en.htm. Cited 5 Nov 2007

European Commission (2003b) The European Union labour force survey Methods and definitions - 2001. Luxembourg: Office for Official Publication of the European Communities. http://epp.eurostat.ec.europa.eu/cache/ITY_OFFPUB/KS-BF-03-002/EN/KS-BF-03-002-

EN.PDF. Cited 3 Jan 2008

European Commission (2005) Structures of the taxation systems in the European Union - Data 1995-2003. Luxembourg: Office for Official Publication of the European Communities. http://epp.eurostat.cec.eu.int/cache/ITY_OFFPUB/KS-DU-05-001/EN/KS-DU-05-001-EN.PDF.

Cited 5 Nov 2007

European Commission (2006) European Union Labour Force Survey Quality report 2004. Luxembourg: Office for Official Publication of European Communities. http://epp.eurostat.ec.europa.eu/cache/ITY_OFFPUB/KS-CC-06-007/EN/KS-CC-06-007-

EN.PDF. Cited 3 Jan 2008 
Eurostat (2005) European Union foreign direct investment yearbook 2005 - Data 1998-2003. Luxembourg: Office for Official Publication of European Communities. http://epp.eurostat.ec.europa.eu/cache/ITY_OFFPUB/KS-BK-05-001/EN/KS-BK-05-001-

EN.PDF. Cited 3 Jan 2008

Eurostat database (2007). Economy and Finance: Monthly labour costs. http://epp.eurostat.cec.eu.int. Cited 5 Nov 2007

Geishecker, Ingo (2006) Does Outsourcing to Central and Eastern Europe Really Threaten Manual Workers’ Jobs in Germany? The World Economy 29: 559-583.

Gera, Surendra; Gu, Wulong; Lin, Zhengxi (2001) Technology and the demand for skills in Canada: an industry-level analysis. Canadian Journal of Economics 34: 132-148.

Kang, Seoghoon; Hong, Dong-Pyo (2002) Technological Change and Demand for Skills in Developing Countries: An Empirical Investigation of The Republic of Korea's Case. The Developing Economies 40: 188-207.

Kelly, Ross (2007) Changing Skill Intensity in Australian Industry. The Australian Economic Review 40:62-79.

Kijima, Yoko (2006) Why did wage inequality increase? Evidence from urban India 1983-99. Journal of Development Economics 81: 97- 117.

Leamer, Edward E. (1984) Sources of Comparative Advantage, Theory and Evidence. MIT Press Cambridge MA.

Leamer, Edward E. (1992) Testing Trade Theory. NBER Working Paper No. 3957, National Bureau of Economic Research, Cambridge MA. http://www.nber.org/papers/W3957. Cited 5 Nov 2007

Machin, Stephen; Van Reenen, John (1998) Technology and Changes in Skill Structure: Evidence from seven OECD Countries. The Quarterly Journal of Economics 113: 1215-1244.

Minondo, Asier; Rubert, Gloria (2006) The effect of outsourcing on the demand for skills in the Spanish manufacturing industry. Applied Economics Letters 13: 599-604.

Morrison Paul, Catherine, J.; Siegel, Donald, S. (2001) The Impact of Technology, Trade and Outsourcing on Employment and Labor Composition. Scandinavian Journal of Economics 103: 241-264.

Piva, Mariacristina; Santarelli, Enrico; Vivarelli, Marco (2005) The skill bias effect of technological and organisational change: Evidence and policy implications. Research Policy 34: 141-157.

Raiser, Martin; Schaffer, Mark; Schuchhardt, Johannes (2004) Benchmarking structural change in transition. Structural Change and Economic Dynamics 15: 47-81.

Sakurai, Kojiro (2001) Biased Technological Change and Japanese Manufacturing Employment. Journal of the Japanese and International Economies 15: 298-322.

Salvanes, Kjell, G.; Førre; Svein, Erik (2003) Effects on Employment of Trade and Technical Change: Evidence from Norway. Economica 70: 293-329.

The Council of the European Union (1999) Council regulation No 126071999. http://eurlex.europa.eu/LexUriServ/site/en/oj/1999/1_161/1_16119990626en00010042.pdf. Cited 5 Nov 2007

Winchester, Niven; Greenaway, David; Reed; Geoffrey V. (2006) Skill Classification and the Effects of Trade on Wage Inequality. Review of World Economics 142: 287-306. 


\section{Appendix A. ISCO classification at one-digit level ('major groups').}

High-skilled non-production occupations

Isco 1 Legislators, senior officials and managers

isco 2 Professionals

isco 3 Technicians and associate professionals

Low-skilled non-production occupations

Isco $4 \quad$ Clerks

Isco $5 \quad$ Service workers and shop and market sales workers

Skilled production occupations

Isco $6 \quad$ Skilled agricultural and fishery workers

Isco $7 \quad$ Craft and related trades workers

Isco 8 Plant and machine operators and assemblers

Unskilled production occupations

Isco $9 \quad$ Elementary occupations

Remaining occupations

isco $0 \quad$ Armed forces

iscoun Occupational group unknown 


\section{Appendix B. NACE classification at one-digit level.}

a Agriculture, hunting and forestry

b Fishing

c Mining and quarrying

d Manufacturing

e Electricity, gas and water supply

f Construction

g Wholesale and retail trade; repair of motor vehicles, motorcycles and personal and household goods

h Hotels and restaurants

i Transport, storage and communication

j $\quad$ Financial intermediation

$\mathrm{k} \quad$ Real estate, renting and business activities

l Public administration and defence; compulsory social security

m Education

n Health and social work

o Other community, social and personal service activities

p Private households with employed persons

q Extra-territorial organizations and bodies

un Sector unknown 
Appendix C. Total differences in occupational shares between countries and EU averages.

Table C.1. Differences between member country's and EU average occupational structures in 2004.

\begin{tabular}{|c|c|c|c|c|c|c|c|c|c|c|c|}
\hline & isco1 & isco2 & isco3 & isco4 & isco5 & isco6 & isco7 & isco8 & isco9 & isco0 & iscoun \\
\hline Belgium & 0.025 & 0.0608 & -0.0426 & 0.0517 & -0.0259 & -0.0197 & -0.037 & -0.0128 & -0.0005 & 0.0017 & -0.0007 \\
\hline Austria & -0.0253 & -0.0447 & 0.0773 & 0.026 & 0.0067 & 0.0045 & -0.0067 & -0.0323 & -0.0006 & -0.0027 & -0.0022 \\
\hline Denmark & -0.0161 & 0.0073 & 0.0558 & -0.0047 & 0.0159 & -0.0165 & -0.0261 & -0.0294 & 0.0174 & -0.0018 & -0.0017 \\
\hline Finland & 0.0048 & 0.0313 & 0.0106 & -0.0288 & 0.0231 & 0.0044 & -0.0236 & -0.0072 & -0.0113 & -0.0023 & -0.001 \\
\hline France & -0.0115 & -0.0164 & 0.0284 & 0.0267 & -0.012 & -0.0008 & -0.0165 & 0.0023 & -0.0051 & 0.0059 & -0.0011 \\
\hline Germany & -0.0282 & 0.0016 & 0.0617 & 0.0238 & -0.0157 & -0.0241 & 0.0144 & -0.0238 & -0.0191 & 0 & 0.0093 \\
\hline Greece & 0.0172 & -0.0006 & -0.0731 & 0.0114 & 0.0029 & 0.0775 & 0.0113 & -0.0192 & -0.0328 & 0.0079 & -0.0024 \\
\hline Ireland & 0.0882 & 0.0313 & -0.0869 & 0.025 & 0.02 & -0.0364 & -0.009 & -0.0166 & -0.0109 & -0.0022 & -0.0024 \\
\hline Italy & 0.0054 & -0.0404 & 0.0478 & 0.0162 & -0.0297 & -0.0174 & 0.024 & -0.0037 & -0.005 & 0.0052 & -0.0024 \\
\hline Luxembourg & -0.0157 & 0.0551 & 0.0352 & 0.0498 & -0.0575 & -0.0238 & -0.0442 & -0.0205 & 0.0272 & -0.0038 & -0.0018 \\
\hline Netherlands & 0.0179 & 0.049 & 0.0337 & 0.0194 & -0.001 & -0.028 & -0.0531 & -0.0334 & -0.0101 & -0.0016 & 0.0071 \\
\hline Portugal & 0.0032 & -0.0553 & -0.0663 & -0.0032 & -0.0032 & 0.0663 & 0.0464 & -0.0124 & 0.0264 & 0.0004 & -0.0024 \\
\hline Spain & -0.0135 & -0.0126 & -0.0447 & -0.0133 & 0.0127 & -0.0089 & 0.0286 & 0.0009 & 0.0542 & -0.001 & -0.0024 \\
\hline Sweden & -0.0344 & 0.0418 & 0.0532 & -0.0069 & 0.0528 & -0.0186 & -0.0478 & 0.0048 & -0.0404 & -0.0038 & -0.0008 \\
\hline UK & 0.0582 & -0.0054 & -0.0272 & 0.0394 & 0.0344 & -0.0322 & -0.0479 & -0.0274 & 0.0109 & -0.0029 & -0.0001 \\
\hline Czech Republic & -0.023 & -0.0359 & 0.0543 & -0.0225 & -0.0111 & -0.0257 & 0.0524 & 0.0566 & -0.0399 & -0.0032 & -0.002 \\
\hline Cyprus & -0.0626 & -0.013 & -0.022 & 0.0263 & 0.035 & -0.0109 & 0.009 & -0.0403 & 0.0751 & 0.0057 & -0.0024 \\
\hline Estonia & 0.0455 & -0.0233 & -0.018 & -0.0595 & -0.0043 & -0.0222 & 0.0053 & 0.0543 & 0.0256 & -0.0011 & -0.0024 \\
\hline Hungary & -0.0137 & -0.0071 & -0.0195 & -0.0138 & 0.0053 & -0.0124 & 0.0447 & 0.0291 & -0.015 & -0.0019 & 0.0043 \\
\hline Latvia & 0.0145 & -0.0257 & -0.0342 & -0.0383 & 0.0075 & 0.0397 & 0.0046 & 0.008 & 0.0302 & -0.0039 & -0.0024 \\
\hline Lithuania & -0.0126 & 0.0191 & -0.0626 & -0.063 & -0.0214 & 0.0895 & 0.044 & -0.0014 & 0.0137 & -0.0029 & -0.0024 \\
\hline Malta & 0.0032 & -0.0391 & -0.0116 & 0.0121 & 0.0182 & -0.0245 & -0.0006 & 0.0121 & 0.0247 & 0.0079 & -0.0024 \\
\hline Poland & -0.0254 & -0.0159 & -0.0218 & -0.0317 & -0.0171 & 0.1187 & 0.0181 & -0.0004 & -0.0226 & 0.0003 & -0.0022 \\
\hline Slovakia & -0.021 & -0.0369 & 0.0308 & -0.0393 & 0.0049 & -0.0305 & 0.0521 & 0.0495 & -0.0077 & 0.0005 & -0.0024 \\
\hline Slovenia & -0.0254 & -0.0059 & 0.0063 & -0.0125 & -0.0219 & 0.041 & -0.0125 & 0.0637 & -0.0429 & -0.0016 & 0.0117 \\
\hline $\begin{array}{l}\text { EU25 cross- } \\
\text { country average }\end{array}$ & 0.0871 & 0.1412 & 0.1499 & 0.1018 & 0.1341 & 0.0432 & 0.1423 & 0.0952 & 0.0967 & 0.0061 & 0.0024 \\
\hline
\end{tabular}

Source: Labour Force Surveys from 25 EU countries, authors’ calculations. 
Appendix D. The industrial, within and interaction effects.

Table D.1. Between effects of the EU-25 countries' occupational structures in 2004.

\begin{tabular}{|c|c|c|c|c|c|c|c|c|c|c|c|}
\hline & isco1 & isco2 & isco3 & isco4 & isco5 & isco6 & isco7 & isco8 & isco9 & isco0 & iscoun \\
\hline Belgium & -0.0039 & 0.0235 & 0.0177 & 0.0079 & 0.0022 & -0.0257 & -0.0141 & -0.0043 & -0.0053 & 0.0026 & -0.0007 \\
\hline Austria & 0.005 & -0.0061 & 0.0023 & 0.0041 & 0.0135 & -0.0083 & -0.0048 & -0.0024 & -0.0025 & -0.0004 & -0.0004 \\
\hline Denmark & -0.0053 & 0.0198 & 0.0222 & 0.0014 & 0.0114 & -0.0193 & -0.0151 & -0.0084 & -0.0055 & -0.0011 & -0.0002 \\
\hline Finland & -0.0046 & 0.0147 & 0.0142 & -0.0015 & 0.0014 & -0.0082 & -0.0124 & -0.0008 & -0.0011 & -0.0018 & 0.0001 \\
\hline France & -0.0043 & 0.0106 & 0.0112 & 0.0019 & 0.0057 & -0.0136 & -0.0138 & -0.0076 & 0.0085 & 0.0016 & -0.0005 \\
\hline Germany & -0.0015 & 0.0024 & 0.0128 & 0.0044 & 0.0009 & -0.0247 & 0.0051 & 0.0049 & -0.004 & 0.0005 & -0.0007 \\
\hline Greece & 0.006 & -0.0165 & -0.0169 & -0.0052 & 0.0124 & 0.0407 & -0.0135 & -0.0125 & 0.0055 & 0.0008 & -0.0009 \\
\hline Ireland & 0.0029 & -0.0054 & -0.0002 & 0.0003 & 0.0065 & 0.0006 & 0.0073 & -0.0082 & -0.001 & -0.0019 & -0.0008 \\
\hline Italy & 0.0025 & 0.0002 & -0.0026 & -0.0006 & 0.0012 & -0.0129 & 0.0092 & 0.0025 & 0.002 & -0.0006 & -0.0009 \\
\hline Luxembourg & -0.0006 & 0.0165 & 0.0243 & 0.0304 & -0.008 & -0.0258 & -0.0225 & -0.019 & -0.0001 & 0.0046 & 0.0002 \\
\hline Netherlands & 0.0023 & 0.0168 & 0.0201 & 0.0052 & 0.0125 & -0.02 & -0.03 & -0.017 & -0.0033 & 0.0011 & 0.0124 \\
\hline Portugal & 0.0014 & -0.0262 & -0.0217 & -0.0145 & -0.0006 & 0.0378 & 0.0168 & -0.0041 & 0.013 & -0.0007 & -0.001 \\
\hline Spain & 0.0036 & -0.0197 & -0.0152 & -0.0066 & 0.0125 & -0.0041 & 0.0213 & -0.0051 & 0.0151 & -0.0009 & -0.001 \\
\hline Sweden & -0.0062 & 0.0449 & 0.0225 & -0.0006 & 0.0058 & -0.0243 & -0.025 & -0.0126 & -0.0028 & -0.0011 & -0.0006 \\
\hline UK & 0.0005 & 0.0249 & 0.0171 & 0.0073 & 0.0149 & -0.0317 & -0.0165 & -0.0143 & -0.0019 & -0.0002 & -0.0001 \\
\hline Czech Republic & -0.0009 & -0.0167 & -0.0075 & -0.0012 & -0.0156 & -0.0118 & 0.0341 & 0.0268 & -0.0059 & -0.0005 & -0.0008 \\
\hline Cyprus & 0.008 & -0.0186 & -0.0139 & 0.0004 & 0.0344 & -0.0059 & -0.001 & -0.0213 & 0.0191 & -0.0001 & -0.001 \\
\hline Estonia & -0.0022 & -0.0037 & -0.0071 & 0.0001 & -0.0179 & -0.0054 & 0.0168 & 0.0238 & -0.0035 & -0.0001 & -0.0008 \\
\hline Hungary & -0.0009 & 0.001 & -0.0041 & -0.0006 & -0.0095 & -0.0065 & 0.0133 & 0.013 & -0.0051 & 0.0002 & -0.0008 \\
\hline Latvia & -0.0011 & -0.0138 & -0.017 & -0.0033 & -0.0176 & 0.0449 & 0.0019 & 0.0095 & -0.0022 & -0.0004 & -0.0009 \\
\hline Lithuania & -0.0017 & -0.0086 & -0.0195 & -0.015 & -0.017 & 0.064 & 0.0017 & 0.0007 & -0.0017 & -0.0019 & -0.001 \\
\hline Malta & 0.0035 & -0.0005 & -0.0008 & 0.0057 & 0.0172 & -0.0259 & -0.0001 & 0.006 & -0.0059 & 0.0016 & -0.0007 \\
\hline Poland & -0.0005 & -0.0146 & -0.0167 & -0.0099 & -0.0276 & 0.0722 & -0.006 & 0.0082 & -0.0036 & -0.0005 & -0.0009 \\
\hline Slovakia & -0.0028 & -0.009 & -0.007 & -0.004 & -0.0184 & -0.0077 & 0.033 & 0.0203 & -0.0042 & 0 & -0.0002 \\
\hline Slovenia & 0.001 & -0.0157 & -0.0141 & -0.0061 & -0.0203 & 0.0216 & 0.0141 & 0.0219 & -0.0036 & -0.0008 & 0.0021 \\
\hline
\end{tabular}

Source: Labour Force Surveys from 25 EU countries, authors’ calculations. 
Table D.2. Within effect of the EU25 countries' occupational structures in 2004.

\begin{tabular}{|c|c|c|c|c|c|c|c|c|c|c|c|}
\hline & isco1 & isco2 & isco3 & isco4 & isco5 & isco6 & isco7 & isco8 & isco9 & isco0 & iscoun \\
\hline Belgium & 0.0279 & 0.0285 & -0.0474 & 0.0372 & -0.0279 & 0.0164 & -0.0244 & -0.0093 & -0.0023 & -0.0007 & -0.0011 \\
\hline Austria & -0.0291 & -0.0406 & 0.0766 & 0.0214 & -0.0036 & 0.0146 & -0.0028 & -0.0317 & -0.0003 & -0.0024 & -0.0021 \\
\hline Denmark & -0.0141 & -0.0018 & 0.0306 & -0.0037 & -0.0073 & 0.0050 & -0.0119 & -0.0223 & 0.0278 & -0.0009 & -0.0015 \\
\hline Finland & 0.0093 & 0.0217 & -0.0007 & -0.0237 & 0.0140 & 0.0141 & -0.0093 & -0.0057 & -0.0180 & -0.0006 & -0.0011 \\
\hline France & -0.0080 & -0.0200 & 0.0196 & 0.0234 & -0.0195 & 0.0179 & -0.0057 & 0.0109 & -0.0210 & 0.0034 & -0.0010 \\
\hline Germany & -0.0279 & 0.0002 & 0.0444 & 0.0190 & -0.0161 & 0.0015 & 0.0082 & -0.0254 & -0.0153 & -0.0006 & 0.0089 \\
\hline Greece & 0.0053 & 0.0227 & -0.0549 & 0.0206 & -0.0103 & 0.0171 & 0.0347 & -0.0055 & -0.0365 & 0.0060 & -0.0024 \\
\hline Ireland & 0.0857 & 0.0382 & -0.0867 & 0.0283 & 0.0164 & -0.0366 & -0.0197 & -0.0086 & -0.0142 & -0.0006 & -0.0024 \\
\hline Italy & 0.0029 & -0.0395 & 0.0503 & 0.0161 & -0.0313 & -0.0068 & 0.0118 & -0.0067 & -0.0036 & 0.0062 & -0.0024 \\
\hline Luxembourg & -0.0044 & 0.0291 & 0.0022 & 0.0307 & -0.0475 & 0.0015 & -0.0342 & 0.0123 & 0.0166 & -0.0047 & -0.0016 \\
\hline Netherlands & 0.0302 & 0.0318 & 0.0057 & 0.0175 & -0.0122 & -0.0179 & -0.0316 & -0.0195 & -0.0097 & -0.0014 & 0.0071 \\
\hline Portugal & 0.0029 & -0.0316 & -0.0482 & 0.0170 & 0.0059 & 0.0153 & 0.0291 & -0.0066 & 0.0144 & 0.0012 & -0.0024 \\
\hline Spain & -0.0193 & 0.0152 & -0.0366 & -0.0050 & 0.0060 & -0.0047 & 0.0067 & 0.0070 & 0.0303 & -0.0002 & -0.0024 \\
\hline Sweden & -0.0311 & 0.0061 & 0.0421 & -0.0060 & 0.0187 & 0.0101 & -0.0242 & 0.0229 & -0.0356 & -0.0034 & 0.0004 \\
\hline UK & 0.0570 & -0.0213 & -0.0387 & 0.0297 & 0.0157 & -0.0064 & -0.0365 & -0.0156 & 0.0182 & -0.0025 & 0.0002 \\
\hline Czech Republic & -0.0221 & -0.0185 & 0.0685 & -0.0215 & 0.0041 & -0.0192 & 0.0142 & 0.0269 & -0.0297 & -0.0030 & 0.0004 \\
\hline Cyprus & -0.0618 & 0.0190 & -0.0168 & 0.0244 & 0.0062 & -0.0050 & 0.0094 & -0.0265 & 0.0447 & 0.0058 & -0.0024 \\
\hline Estonia & 0.0450 & -0.0190 & -0.0058 & -0.0603 & 0.0171 & -0.0194 & -0.0099 & 0.0246 & 0.0251 & -0.0010 & -0.0024 \\
\hline Hungary & -0.0128 & -0.0083 & -0.0078 & -0.0143 & 0.0123 & -0.0075 & 0.0276 & 0.0152 & -0.0093 & -0.0021 & 0.0040 \\
\hline Latvia & 0.0158 & -0.0047 & -0.0170 & -0.0423 & 0.0280 & -0.0006 & 0.0039 & -0.0041 & 0.0243 & -0.0038 & -0.0024 \\
\hline Lithuania & -0.0023 & 0.0392 & -0.0415 & -0.0572 & -0.0055 & 0.0097 & 0.0451 & 0.0017 & 0.0117 & -0.0015 & -0.0024 \\
\hline Malta & -0.0021 & -0.0370 & -0.0119 & 0.0071 & 0.0006 & 0.0033 & 0.0015 & 0.0052 & 0.0278 & 0.0047 & -0.0024 \\
\hline Poland & -0.0138 & 0.0020 & 0.0016 & -0.0233 & 0.0098 & 0.0142 & 0.0191 & -0.0005 & -0.0079 & 0.0008 & -0.0021 \\
\hline Slovakia & -0.0184 & -0.0280 & 0.0418 & -0.0344 & 0.0318 & -0.0278 & 0.0159 & 0.0287 & -0.0081 & 0.0008 & -0.0024 \\
\hline Slovenia & -0.0206 & 0.0127 & 0.0263 & -0.0054 & -0.0069 & 0.0112 & -0.0197 & 0.0292 & -0.0342 & -0.0007 & 0.0052 \\
\hline
\end{tabular}

Source: Labour Force Surveys from 25 EU countries, authors' calculations. 
Table D.3. Interaction effect of the EU25 countries' occupational structures in 2004.

\begin{tabular}{|c|c|c|c|c|c|c|c|c|c|c|c|}
\hline & isco1 & isco2 & isco3 & isco4 & isco5 & isco6 & isco7 & isco8 & isco9 & isco0 & iscoun \\
\hline Belgium & 0.001 & 0.0088 & -0.0129 & 0.0066 & -0.0003 & -0.0104 & 0.0015 & 0.0008 & 0.0071 & -0.0002 & 0.0011 \\
\hline Austria & -0.0012 & 0.0019 & -0.0016 & 0.0004 & -0.0031 & -0.0019 & 0.001 & 0.0018 & 0.0022 & 0.0001 & 0.0003 \\
\hline Denmark & 0.0032 & -0.0108 & 0.0031 & -0.0024 & 0.0117 & -0.0023 & 0.0009 & 0.0013 & -0.0049 & 0.0001 & 0 \\
\hline Finland & 0.0001 & -0.0051 & -0.0029 & -0.0037 & 0.0077 & -0.0015 & -0.0018 & -0.0007 & 0.0078 & 0.0001 & 0 \\
\hline France & 0.0007 & -0.007 & -0.0024 & 0.0014 & 0.0018 & -0.0051 & 0.0029 & -0.001 & 0.0074 & 0.0009 & 0.0004 \\
\hline Germany & 0.0012 & -0.001 & 0.0045 & 0.0004 & -0.0004 & -0.0008 & 0.0011 & -0.0033 & 0.0002 & 0.0001 & 0.0012 \\
\hline Greece & 0.0059 & -0.0068 & -0.0014 & -0.004 & 0.0008 & 0.0196 & -0.01 & -0.0012 & -0.0018 & 0.001 & 0.0009 \\
\hline Ireland & -0.0003 & -0.0016 & 0 & -0.0037 & -0.0029 & -0.0004 & 0.0033 & 0.0002 & 0.0043 & 0.0003 & 0.0008 \\
\hline Italy & 0 & -0.0011 & 0.0001 & 0.0007 & 0.0004 & 0.0023 & 0.003 & 0.0005 & -0.0034 & -0.0004 & 0.0009 \\
\hline Luxembourg & -0.0107 & 0.0095 & 0.0087 & -0.0112 & -0.0019 & 0.0005 & 0.0124 & -0.0138 & 0.0107 & -0.0036 & -0.0004 \\
\hline Netherlands & -0.0147 & 0.0005 & 0.0079 & -0.0033 & -0.0012 & 0.0099 & 0.0085 & 0.0032 & 0.0029 & -0.0012 & -0.0125 \\
\hline Portugal & -0.0011 & 0.0026 & 0.0036 & -0.0056 & -0.0084 & 0.0133 & 0.0005 & -0.0017 & -0.001 & 0 & 0.001 \\
\hline Spain & 0.0022 & -0.0081 & 0.0071 & -0.0018 & -0.0058 & -0.0001 & 0.0006 & -0.001 & 0.0088 & 0.0001 & 0.001 \\
\hline Sweden & 0.0029 & -0.0092 & -0.0114 & -0.0003 & 0.0283 & -0.0044 & 0.0015 & -0.0055 & -0.002 & 0.0007 & -0.0006 \\
\hline UK & 0.0007 & -0.009 & -0.0056 & 0.0023 & 0.0038 & 0.0059 & 0.0051 & 0.0025 & -0.0054 & -0.0002 & -0.0002 \\
\hline Czech Republic & -0.0001 & -0.0007 & -0.0067 & 0.0002 & 0.0004 & 0.0053 & 0.0042 & 0.0029 & -0.0042 & 0.0003 & -0.0016 \\
\hline Cyprus & -0.0089 & -0.0133 & 0.0088 & 0.0015 & -0.0056 & 0 & 0.0006 & 0.0076 & 0.0114 & 0 & 0.001 \\
\hline Estonia & 0.0028 & -0.0006 & -0.0051 & 0.0007 & -0.0035 & 0.0026 & -0.0015 & 0.0059 & 0.0039 & 0.0001 & 0.0008 \\
\hline Hungary & 0 & 0.0002 & -0.0076 & 0.0012 & 0.0025 & 0.0016 & 0.0038 & 0.0009 & -0.0006 & 0 & 0.0011 \\
\hline Latvia & -0.0002 & -0.0072 & -0.0001 & 0.0073 & -0.0029 & -0.0046 & -0.0012 & 0.0026 & 0.0081 & 0.0003 & 0.0009 \\
\hline Lithuania & -0.0086 & -0.0114 & -0.0016 & 0.0092 & 0.0011 & 0.0159 & -0.0028 & -0.0039 & 0.0037 & 0.0005 & 0.001 \\
\hline Malta & 0.0017 & -0.0016 & 0.001 & -0.0007 & 0.0004 & -0.0019 & -0.0021 & 0.0009 & 0.0028 & 0.0016 & 0.0007 \\
\hline Poland & -0.0111 & -0.0033 & -0.0067 & 0.0015 & 0.0007 & 0.0323 & 0.005 & -0.0081 & -0.0111 & 0 & 0.0008 \\
\hline Slovakia & 0.0002 & 0.0002 & -0.004 & -0.0009 & -0.0085 & 0.005 & 0.0032 & 0.0005 & 0.0045 & -0.0004 & 0.0002 \\
\hline Slovenia & -0.0058 & -0.0029 & -0.0059 & -0.001 & 0.0054 & 0.0082 & -0.0068 & 0.0125 & -0.0051 & -0.0001 & 0.0045 \\
\hline
\end{tabular}

Source: Labour Force Surveys from 25 EU countries, authors’ calculations. 